\title{
Decentralisation, Local Communities and Forest Management in Barito Selatan District, Central Kalimantan
}

John F. McCarthy
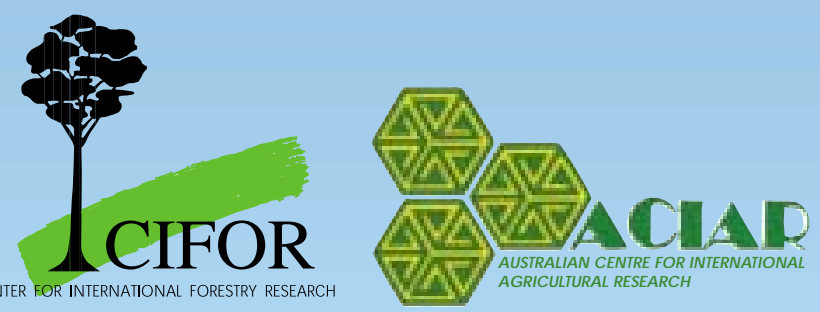


\section{CIFOR REPORTS ON DECENTRALISATION AND FORESTS IN INDONESIA}

\section{Synthesis of Major Findings}

Barr, C. and Resosudarmo, I.A.P. 2002. Decentralisation of forest administration in Indonesia: Implications for forest sustainability, community livelihoods, and economic development. Center for International Forestry Research, Bogor, Indonesia.

\section{District and Provincial Case Studies}

Case Study 1. McCarthy, J.F. 2001. Decentralisation, local communities and forest management in Barito Selatan District, Central Kalimantan. Center for International Forestry Research, Bogor, Indonesia.

Case Study 2. McCarthy, J.F. 2001. Decentralisation and forest management in Kapuas District, Central Kalimantan. Center for International Forestry Research, Bogor, Indonesia.

Case Study 3. Barr, C., Wollenberg, E., Limberg, G., Anau, N., Iwan, R., Sudana, I.M., Moeliono, M., and Djogo, T. 2001. The Impacts of decentralisation on forests and forestdependent communities in Malinau District, East Kalimantan. Center for International Forestry Research, Bogor, Indonesia.

Case Study 4. Casson, A. 2001. Decentralisation of policymaking and administration of policies affecting forests and estate crops in Kutai Barat District, East Kalimantan. Center for International Forestry Research, Bogor, Indonesia.

Case Study 5. Casson, A. 2001. Decentralisation of policymaking and administration of policies affecting forests and estate crops in Kotawaringin Timur District. Central Kalimantan. Center for International Forestry Research, Bogor, Indonesia.

Case Studies 6 and 7. Potter, L. and Badcock, S. 2001. The effects of Indonesia's decentralisation on forests and estate crops: Case study of Riau province, the original districts of Kampar and Indragiri Hulu. Center for International Forestry Research, Bogor, Indonesia.

Case Study 8. Soetarto, E., Sitorus, M.T.F. and Napiri, Y. 2001. Decentralisation of administration, policy making and forest management in West Kalimantan. Center for International Forestry Research, Bogor, Indonesia.

Case Study 9. Obidzinski, K. and Barr, C. 2002. The effects of decentralisation on forests and forest Industries in Berau District, East Kalimantan. Center for International Forestry Research, Bogor, Indonesia. 


\section{Decentralisation, Local Communities and Forest Management in Barito Selatan District, Central Kalimantan}

John F. McCarthy

Asia Research Centre, Murdoch University, Murdoch, WA6150, Australia 
(C) 2001 by Center for International Forestry Research All rights reserved. Published in 2001

Printed by SMK Grafika Desa Putera, Indonesia

\section{ISBN 979-8764-76-5}

\section{Published by}

Center for International Forestry Research

Mailing address: P.O. Box 6596 JKPWB, Jakarta 10065, Indonesia

Office address: Jl. CIFOR, Situ Gede, Sindang Barang, Bogor Barat 16680, Indonesia

Tel.: +62 (251) 622622; Fax: +62 (251) 622100

E-mail: cifor@cgiar.org

Web site: http://www.cifor.cgiar.org 


\title{
Decentralisation and Forests in Indonesia: An Overview of the Study
}

\begin{abstract}
ince early-2000, the Center for International Forestry Research (CIFOR) has
conducted research on the decentralisation of forest administration and policies affecting forests in Indonesia. This project has sought to document the real and anticipated impacts of decentralisation on forest management, forest community livelihoods, and economic development at the provincial and district levels. During the initial phase of this research, CIFOR conducted case studies in nine kabupaten or districts, in four provinces: Riau, East Kalimantan, Central Kalimantan, and West Kalimantan. These case studies were carried out in 2000, with follow up visits to some districts conducted in early 2001 . As such, the findings presented in the present report and the companion case studies reflect the conditions and processes that existed in the study districts during the initial phase of Indonesia's decentralisation process.
\end{abstract}

The following reports have been produced by this project. The first of these represents a synthesis of the major findings from the nine case studies, accompanied by a historical analysis of forest administration and forestry sector development in Indonesia, and a discussion of the origins and legal-regulatory basis of the nation's ongoing decentralisation process. Each of the nine case studies is published as a separate report (with the exception of the study districts in Riau, which have been combined) in order to make the information contained therein more readily accessible to decision-makers involved in the decentralisation process. It is hoped that readers of the case studies will refer to the synthesis report in order to situate the specific case study findings in a broader historical and policy context.

During 2002, CIFOR will publish additional case studies from research on decentralisation and forests in West Kalimantan, South Sulawesi and Irian Jaya. CIFOR also plans to carry out follow-up research at several of the original case study districts, and will publish periodic findings from the sites.

\section{Acknowledgements and Disclaimer}

CIFOR gratefully acknowledges the financial support of the Australian Center for International Agricultural Research (ACIAR) and the United Kingdom's Department for International Development (DFID). The opinions expressed in this report are the views of the author(s) and do not necessarily represent the official policy of CIFOR. These opinions, likewise, do not represent the official policy of ACIAR or DFID or any other organization involved in funding, conducting or disseminating this study.

The author gratefully acknowledges the assistance of the academics, government officials, NGO workers and members of the local community in Central Kalimantan who provided hospitality, information, essential advice and other generous assistance during the course of this research. 


\section{Editor's Preface}

\section{Overview of Indonesia's Decentralisation Process}

Since late-1998, Indonesia has undergone a process of rapid and far-reaching decentralisation. With this process, considerable degrees of administrative and regulatory authority have been transferred from the national government in Jakarta to the country's provincial and district governments. This transfer of authority has occurred across broad segments of the nation's economy and has sharply redefined the roles and responsibilities of government agencies at each level of the nation's administrative structure. With the locus of decision-making shifting decisively away from the national government, Indonesia's ongoing decentralisation process marks a dramatic break from the highly-centralized system of governance that characterized Suharto's New Order regime during the period 1966-1998.

To a significant extent, the process of decentralisation now occurring in Indonesia has been driven by the demands of provincial and district governments whose jurisdictions are rich in timber, petroleum, and other natural resources. Officials from resource-rich regions have long complained that the vast majority of the benefits from these assets have flowed away from their regions to the national government and to private sector companies closely associated with decision-makers in Jakarta. While the New Order government kept a tight lid on calls for greater regional autonomy and regional control over natural resource revenues, the post-Suharto government has not been able to ignore these demands. On the contrary, since 1998 the country's senior leadership has recognized that its ability to maintain Indonesia's integrity as a nation may ultimately depend on its capacity to strike a more equitable balance of power between the national government, on the one hand, and the provincial and district governments, on the other.

Over the last three years, the national government has issued several important pieces of legislation aimed at transferring authority to the provincial and district governments, and at allowing resource-rich regions to retain a larger share of the fiscal revenues generated within their jurisdictions. The most significant of these have been Law 22 on Regional Governance and Law 25 on Fiscal Balancing, both of which were issued in May 1999. Together, these laws provide the legal basis for regional autonomy, laying out a broad framework for the decentralisation of administrative and regulatory authority primarily to the district level. These laws have been supported by a variety of implementing regulations and sector-specific decentralisation laws, including Law 41 of 1999, a revised version of Indonesia's Basic Forestry Law, which outlines the division of administrative authority in the forestry sector under regional autonomy. 
In many parts of Indonesia, provincial and district officials acting in the spirit of regional autonomy have instituted reforms that extend well beyond the authority granted to them under the national government's decentralisation laws and regulations. Indeed, the formal decentralisation process has been driven, to a significant degree, not by policy decisions made at the national level but, rather, by decisions made by provincial and district level actors. This process has often been ad hoc in nature, with national policymakers frequently finding themselves in the position of having to react to fast-moving changes that have occurred in the provinces and districts. Far from being a well-planned and carefully-managed exercise in bureaucratic reorganization, the implementation of regional autonomy in Indonesia has been characterized by intense struggles among the different levels of government, each of which represents a competing set of political and economic interests. In this way, regional autonomy has stretched well beyond the formal decentralisation of administrative and regulatory authority; in practice, it also involves a significant, if largely informal and unplanned, devolution of power from the national government to its provincial and district-level counterparts.

The formal and informal processes of decentralisation have been accompanied by a wide-ranging set of governance and economic reforms, collectively known as reformasi, that are associated with Indonesia's transition away from Suharto's New Order regime. Broadly defined, reformasi refers to the transformation and dismantling of the policies, practices, and institutional structures through which the New Order leadership and a handful of well-connected conglomerates controlled the political and economic life of the country prior to Suharto's resignation in May 1998. While significant elements of the reformasi agenda coincide with the changes occurring under regional autonomy, these reform processes are also quite distinct. Whereas reformasi refers to a shift away from the constellation of interests and power structures that have supported a particular regime, decentralisation and regional autonomy refer to the transfer of authority from the national government to Indonesia's provincial and district governments.

\section{Decentralisation of Forest Administration}

The formal and informal processes of decentralisation that are now occurring in Indonesia have far-reaching implications for forest management and for the livelihoods of communities living in and around forested areas. On the positive side, experience from other countries suggests that decentralized systems of forest management often lead to more sustainable and equitable use of these resources, as decision-makers are physically located closer to where their policies will be implemented (Conyers 1981; Rondinelli, Nellis, and Cheema 1983). This proximity often brings with it improved understanding of the specific biophysical, social, and institutional conditions influencing forest management at the field level; better capacity to monitor the activities of forest user groups; and greater access to local knowledge about the management and utilization of forest resources - which are sometimes highly specific to particular social groups and/or ecosystems (Carney 1995). 
In addition, decentralized forest administration often allows for greater participation on the part of forest communities in policy decision-making processes, and more direct accountability of policymakers to peoples whose livelihoods depend on forests (Brandon and Wells 1992). Decentralisation also frequently implies a more equitable distribution of benefits from forest resources, as local communities and governments in forested regions are able to secure a greater portion of revenues from the extraction of timber and other forest products (Ascher 1995; Ostrom 1990).

In addition to providing opportunities for expanded equity and improved forest management, however, decentralisation also carries significant risks. In many countries, national governments have decentralized without first creating the necessary institutional capacity at the provincial or district levels to administer forests effectively (Rivera 1996). Often, national governments assign tasks to provincial and district governments without giving them adequate resources for carrying out these tasks. Most provincial and district governments lack essential technical skills and must look to other entities for advice, training, and technical information. In cases where local elites have been strong and/or traditionally marginalized groups have been unable to organize themselves, decentralisation has often strengthened pre-existing power relations, rather than promoting democratic decision-making processes (Utting 1993). Finally, even when elite groups do not dominate provincial and district governments, it is often that case that these governments have little interest in sustainable forest management.

\section{Indonesia's Forestry Sector}

The manner in which decentralisation affects forest management, community livelihoods, and economic development is of particular significance in Indonesia due to the scale and importance of the country's forest resources. Indonesia has the world's third largest tract of tropical forests, surpassed in area only by those of Brazil and Congo. In 1997, the country's total forest cover was officially estimated to be 100 million hectares (MOFEC, cited in World Bank 2001). It has been conservatively estimated that at least 20 million people depend on Indonesia's forests for the bulk of their livelihoods (Sunderlin, et al. 2000). Over the last three decades, the national government has allocated over 60 million hectares of forest to commercial logging companies, and Indonesia's forestry sector industries have long ranked second only to petroleum in terms of their contribution to GNP (Barr 2001). The forestry sector currently generates approximately US\$ 7 billion in annual revenues.

Well before the country's ongoing decentralisation process began in late-1998, Indonesia's forestry sector had entered a period of crisis. From the mid-1980s onward, deforestation is estimated to have occurred at a pace of 1.6 million hectares per year (Toha 2000). A major factor driving this high level of deforestation and associated forest degradation has been overcapacity in the nation's wood processing industries. Through the mid-1990s, Indonesia's sawnwood, plywood, and pulp industries are collectively estimated to have consumed 60-80 million cubic meters $\left(\mathrm{m}^{3}\right)$ of wood per year (Barr 2001; Scotland et al. 1998). Log consumption on this scale has stood well above the Indonesian government's own widely-cited sustainable timber harvest threshold 
of 25 million $\mathrm{m}^{3}$ per year. Moreover, with few effective regulatory structures in Indonesia's forestry sector, domestic demand for timber has resulted in large volumes of wood being harvested from illegal sources (ITFMP 1999). At the same time, a decline in the nation's HPH timber concession system, coupled with rapid expansion in oil palm and other forms of agroindustrial plantations, has meant that a growing portion of the nation's wood supply has been obtained through clearing of natural forest rather than selective harvesting at multiple-rotation timber concessions (Barr 2001).

\section{Scope and Methods of the Present Study}

The present study examines the preliminary effects of decentralisation of forest administration in Barito Selatan District, Central Kalimantan. It is one of nine district level case studies carried out during 2000 and early 2001 by the Center for International Forestry Research (CIFOR) in four provinces: Riau, East Kalimantan, Central Kalimantan, and West Kalimantan. The findings presented in these studies reflect the conditions and processes that existed in the study districts during the initial phase of Indonesia's decentralisation process.

Each of the case studies used a rapid appraisal methodology for gathering data at the district and provincial levels. For each case study, preliminary visits were made to the district and provincial capitals to establish initial contacts and to identify key issues. Second visits for data gathering were then carried out for periods of 10-14 days in each district, with shorter amounts of time in the provincial capitals. The collection of primary data involved semi-structured interviews with key informants, including: government officials; forest industry actors; members of communities living in and around forests; political party representatives; officers from the regional military and police force; informal district leaders; representatives from nongovernmental organizations (NGOs); university researchers; and individuals involved with donor agencies and development projects. Data collection also involved the review of primary and secondary documents, including: district and provincial laws and regulations; government statistics; regional news media articles; industry publications; research studies; and reports prepared by NGOs and donor agencies.

Each of these case studies is structured to focus on processes that have occurred at the district and, to a lesser extent, the provincial levels. To avoid repetition, more general information on the history of forest administration and forestry sector development in Indonesia, as well as significant national policy and legal-regulatory reforms associated with decentralisation, has been placed in an accompanying report which synthesizes the project's major findings (see Barr and Resosudarmo 2001). Readers are encouraged to review the case studies in conjunction with this synthesis in order to appreciate the broader historical and policy contexts within which the district and provincial decentralisation processes are now occurring.

Christopher Barr and Ida Aju Pradnja Resosudarmo

Bogor, Indonesia 


\section{Glossary}

\begin{tabular}{|c|c|}
\hline APKINDO & $\begin{array}{l}\text { Asosiasi Panel Kayu Indonesia, Indonesian Wood Panel Producers } \\
\text { Association }\end{array}$ \\
\hline Bapedalda & $\begin{array}{l}\text { Badan Pengendalian Dampak Lingkungan Daerah, Regional Environ- } \\
\text { mental Protection Agency }\end{array}$ \\
\hline BAPPEDA & $\begin{array}{l}\text { Badan Perencanaan Pembangunan Daerah, Regional Development } \\
\text { Planning Agency }\end{array}$ \\
\hline BAPPENAS & $\begin{array}{l}\text { Badan Perencanaan Pembangunan Nasional, National Development } \\
\text { Planning Agency }\end{array}$ \\
\hline Bina Desa & Village Development Programme \\
\hline BPS & Badan Pusat Statistik, Central Statistics Agency \\
\hline BUMD & $\begin{array}{l}\text { Badan Usaha Milik Daerah, District or Provincial Government-Owned } \\
\text { Enterprise }\end{array}$ \\
\hline Camat & Head of Subdistrict \\
\hline Cukong & Entrepreneur backing a commercial venture \\
\hline Dinas Kehutanan & Provincial Forestry Service \\
\hline Dispenda & Dinas Pendapatan Daerah, District Revenue Office \\
\hline DPRD & $\begin{array}{l}\text { Dewan Perwakilan Rakyat Daerah, District or Provincial Legislative } \\
\text { Assembly }\end{array}$ \\
\hline DR & Dana Reboisasi, Reforestation Fund \\
\hline Hasil Pajak & Tax proceeds \\
\hline $\mathrm{HPH}$ & Hak Pengusahaan Hutan, Commercial Forestry Concession \\
\hline $\mathrm{HPHH}$ & Hak Pemungutan Hasil Hutan, Forest Product Harvest Concession \\
\hline HPHKM & $\begin{array}{l}\text { Hak Pengusahaan Hutan Kemasyarakatan, Community Forestry Conces- } \\
\text { sion }\end{array}$ \\
\hline Hutan Rakyat & Community Forest \\
\hline $\mathrm{IHH}$ & Iuran Hasil Hutan, Forest Product Royalty \\
\hline Inhutani & State-owned forestry enterprise \\
\hline IPK & Izin Pemanfaatan Kayu, Timber Clearance Permit \\
\hline KepMen & Keputusan Menteri, Ministerial Decree \\
\hline Komisi Amdal & Environmental Impact Assessment Commission \\
\hline Ladang & Area used for swidden agriculture \\
\hline Muspida & Musyawarah Pimpinan Daerah, District Leadership Council \\
\hline Muspika & Musyawarah Pimpinan Kecamatan, Subdistrict Leadership Council \\
\hline PAD & $\begin{array}{l}\text { Pendapatan Asli Daerah, Regionally Generated Revenues, often refers to } \\
\text { revenues that district governments obtain from sources within their } \\
\text { districts }\end{array}$ \\
\hline
\end{tabular}


Paduserasi

Pajak Daerah

PBB

Pemda

Pesantren

Perda

Perkebunan Rakyat

PKT

PLG

Polsek

PSDH

Reformasi

Retribusi Daerah

RPBI

RTRWK

SAKB

Sawah

SKSHH
Spatial planning reconciliation process

Regional Tax

Pajak Bumi dan Bangunan, Land and Building Tax

Pemerintah Daerah, District or Provincial Government

Islamic boarding school

Peraturan Daerah, District or Provincial Government Regulation

Community-based plantations

Dinas Perhutanan dan Konservasi Tanah, Office for Forestry and Land Conservation

Proyek Lahan Gambut, Million Hectare Peat Lands Project

Polisi Sektor, District-level command of the national police force

Provisi Sumber Daya Hutan, Forest Resource Rent Provision

Reform process aimed at dismantling the political and economic structures of Indonesia's New Order regime

Regional charge or levy

Rencana Pengurusan Bahan baku Industri, operating permit required by sawmills and other wood industries

Rencana Tata Ruang Wilayah Kabupaten, District-Level Spatial Plan

Surat Angkutan Kayu Bulat, Permit to Transport Timber

Irrigated rice

Surat Keterangan Sahnya Hasil Hutan, Permit to transport 


\section{Table of Contents}

Decentralisation and Forests in Indonesia: An Overview of the Study iii

Editor's Preface iv

Glossary viii

Abstract xiii

1 Overview of Barito Selatan 1

1.1 Geography 1

1.2 District Formation 2

1.3 Economy 4

1.4 Forestry 4

2 Decentralisation in Barito Selatan $\quad 7$

$\begin{array}{lll}2.1 & \text { The financial situation } & 7\end{array}$

2.2 Creating a district corporation 9

2.3 Towards a district timber regime 11

2.4 Decentralisation, spatial planning and environmental management 14

2.5 Trends shaping the impact of regional autonomy in Barsel 16

3 The Anticipated Effects of Decentralisation on Forest Dependent Communities in Barsel 19

3.1 Rattan producers in Barsel 19

3.2 Muara Marlungai: The Situation of the Bawo 21

3.3 Patas Village 22

4 Conclusions 25

5. Endnotes 29

6. References 33 


\section{Abstract}

Based on field research carried out in Central Kalimantan during June and July 2000, this chapter examines the likely impact of the decentralisation reforms on forest management in Barito Selatan. Conclusions are derived from three major sources. First, interviews were conducted with key government officials and community figures in the provincial capital, Palangkaraya, and the district capital, Buntok. These were supplemented with information from relevant newspaper and government reports. Thirdly, brief visits were made to a number of communities around the district to examine the implications of these reforms for forest dependent communities and to consider the degree to which local communities are likely to benefit from the new decentralised arrangements.

The first section of this chapter provides an overview of the geographic and economic context, at the same time discussing the forestry sector in the district. The second section examines specific disputes, controversies and decisions regarding land use, forestry regulations, law enforcement, and revenue collection, considering the roles and motivations of different stakeholders during the decentralisation process and the consequent implications for forests and people. The third section considers the situation of forest dependent communities in the district in the midst of the decentralisation process. It examines the fate of village communities dependent on rattan gardens, the circumstances of an isolated and impoverished community living in the middle of a logging concession area, and a hamlet where eleven unlicensed sawmills had opened operations over the previous twelve months. Based on this discussion, the final section draws some conclusions regarding the real and anticipated effects of decentralisation on forest management in the district. 


\subsection{GEOGRAPHY}

$\mathbf{T}$ he giant Barito River dominates Barito Selatan (or as it is locally known, Barsel), a district arranged around its banks north of Banjarmasin, the capital of South Kalimantan. At present Barito Selatan is the smallest district $\left(12,664 \mathrm{~km}^{2}\right)$ in Central Kalimantan with a population of only 177,516 people (Badan Pusat Statistik Kabupaten Daerah Barito Selatan 1998). ${ }^{1}$

Barito Selatan consists of three geographical areas: the flood prone lowlands, the river plains, and the hilly highlands alongside the Barito River. Here, the failed one million-hectare peat lands project (Proyek Lahan Gambut or PLG) extends to the west bank of the Barito River (Rieley 1999). Two hundred thousand hectares (15\%) of PLG lay in the Barito Selatan area, and the project's primary channels connect to the Barito River here. Large numbers of 'wood utilization' forest clearance permits (Ijin Pemanfaatan Kayu or IPK) were granted at the height of PLG, leading to the felling of remnant swamp forests. ${ }^{2}$ According to a local government report, 2,901 transmigrants participated in the PLG project in the district (Pemerintah Kabupaten Barito Selatan 1999a). With the failure of PLG, these transmigrants together with displaced Dayak populations who had farmed fishponds and rattan gardens in the area - face considerable hardship. ${ }^{3}$

The second area consists of the river plains along the Barito riverbanks stretching north from the town of Mengkatip along both banks of the Barito to the border of Barito Utara. While there are also significant areas of lake and swamp, particularly on the West Bank, the peat here tends to be less than 25 centimeters $(\mathrm{cm})$ deep. Most of the river plain area lies between 7 to 25 metres $(\mathrm{m})$ above sea level. While in this area some villagers also cultivate rubber, most primarily depend upon highly productive rattan gardens.

The third area consists of hilly highlands that steadily rise to the east of the river plains. While the land is mostly 25 to $100 \mathrm{~m}$ above sea level, on the border with South Kalimantan hills rises up to $500 \mathrm{~m}$ or more. Here villagers combine shifting agriculture with the cultivation of rubber gardens. This area is the 'hinterland' of Barsel: three subdistricts here produce over $70 \%$ of Barsel's rice (BAPPEDA 1999). ${ }^{4}$

Compared to the neighbouring districts of Central Kalimantan (such as Kapuas), Barito Selatan is well serviced by roads. The highway between Banjarmasin to the south and Muara Teweh to the north is in excellent condition. Another paved road running east-west connects this highway to the district capital of Buntok. The villages and transmigration settlements in the highlands area can be reached either by sealed roads or via logging roads. ${ }^{5}$ However, there are no roads running through the deep peat swamps to the south or on the west bank of the river; only a few roads connect the east bank to 
the wider road system. This means that most of the villages in the lowland and river plain area can only be reached by river.

The provincial government has started constructing a highway connecting Buntok to the provincial capital of Palangkaraya. However, the western half of Central Kalimantan is likely to stay somewhat isolated from the two eastern districts. The project involves constructing a road across extensive swamps and building bridges across three major rivers. According to the government estimates, it will cost Rp 172 billion, and at current levels of funding ( $\mathrm{Rp} 7.5$ billion for two years), this will take 22 years (Banjarmasin Post 2000e). Consequently, visitors from the provincial capital of Palangkaraya still fly or take the arduous overland route via Banjarmasin.

An unfortunate consequence is that all goods and services exit or enter Barsel via the adjoining business centre of Banjarmasin (see map). This creates transportation and other expenses for companies considering working in the Barito area. Businesses need to work across two provinces, creating comparative advantages for the coastal districts that have ready access to an ocean port. For this reason, oil palm plantations development is concentrated in the Kotawaringin area of Central Kalimantan (see Casson 2001). ${ }^{6}$ Moreover, due to the difficulty of access, few people in Palangkaraya have visited the Barito area. Indeed, most people in the western half of Central Kalimantan have little knowledge of the Barito area, and the economy of the Barito area is isolated from the rest of the province. Furthermore, as the service and other industries are much more developed in Banjarmasin, much of the value added processing occurs in South Kalimantan. The Banjarese people of this province obtain jobs processing the raw material produced by various groups of ethnic Dayaks in Central Kalimantan. While profits accrue to Banjarmasin businesses, the South Kalimantan government obtains significant tax revenues. Consequently, people in Barsel like to say that South Kalimantan lives off Central Kalimantan.

\subsection{DISTRICT FORMATION}

Although by the standards of Central Kalimantan, Barsel is a comparatively small district, there are plans to divide the district into two. This division has a historical precedence. Barsel became a district in its one right only when the district of Barito was split into North and South Barito (Barsel) in 1958. Then during an administrative reform in 1964, the government restructured Barsel, preparing East Barito for full district status in its own right by establishing the East Barito Preparatory District (Wilayah Persiapan Kabupaten Barito Timur). East Barito was never to achieve district status: first it became an administrative region (Wilayah Administratif) and finally, with a decision of the Minister of Internal Affairs (Kepmen 4/1979), the area was given a subordinate district status (Wilayah Pembantu Bupati Barito Selatan Wilayah Barito Timur). With its centre at Tamiang Layang, this preparatory district remained a part of Barsel, and its assistant Bupati (pembantu Bupati) has carried out exclusively a coordinating administrative function under the authority of the district head (Pemerintah Kabupaten Barito Selatan 1999a).

At present, with the assistance of the current governor (a former district head of Barsel), the 6 subdistricts of Barito Timur have high level support for achieving district status. The request for Kabupaten status is also backed by the district and provincial legislative assembly (Dewan Perwakilan Rakyat or DPRD) and now awaits consideration by the central government. In the meantime officials and members of the district DPRD proceed to make decisions on the assumption that the kabupaten will continue to exist as a single entity for at least the next few years, and this report will proceed on the same assumption. 


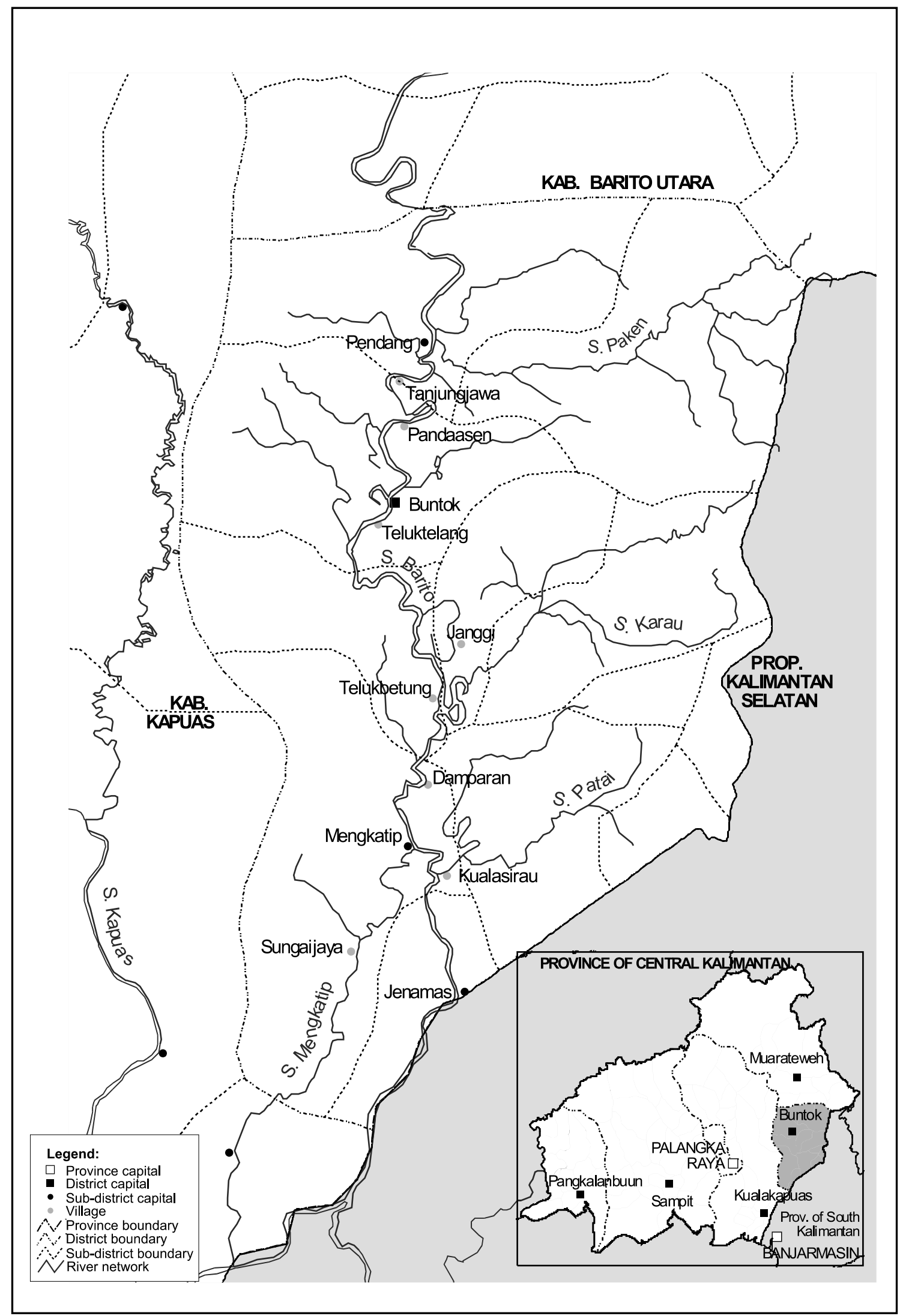




\subsection{ECONOMY}

Only a little over a thousand hectares of land in Barsel are irrigated for wetland rice (sawah). However, a much more extensive area is subject to traditional dry land shifting agriculture (ladang). Sawah and ladang together produce some 37,000 tons of rice per year, and Barsel produces slightly more rice than it consumes (BAPPEDA 1999).

According to the district planning office, BAPPEDA, rubber is the major product of the district. Although commercial firms run three large rubber plantations, community farming produces most of the district's rubber. As elsewhere in Kalimantan, before abandoning swidden fields, farmers plant the area with rubber trees; and when these trees mature, they return to tap the rubber. During 1992-97, the average yield of unprocessed rubber was 27,425 tons/year. Most of this rubber comes from small holder plots, with rubber amounting to $97 \%$ of production from community-based plantations (perkebunan rakyat) (BAPPEDA 1999). Although a rubber factory is under construction in Buntok, at present all Barsel's unprocessed rubber is supplied to Banjarmasin's rubber factories.

In addition to rubber, Barsel has a small sugar plantation (70 ha), and there are also plans to open a 30,000 ha sugar plantation. While Barsel lacks oil palm plantations, there are plans to open two new plantations (Pemerintah Kabupaten Barito Selatan 1999b). ${ }^{7}$

Barsel has significant oil and coal reserves, but mining is still in the exploration phase. While the district government lacks accurate data concerning the oil reserves, a BAPPEDA report notes that oil reserves 'hypothetically' amount to 1,994 million barrels (BAPPEDA 1999). According to a report in the Banjarmasin Post (2000a), there are four significant sources of oil. ${ }^{8}$ In August 2000 the Bupati, H Achmad Diran, said that these reserves are under exploration by Indonesia's state-owned petroleum company, Pertamina. According to the Bupati, these untapped resources form part of the national oil reserves that in the future will help support regional autonomy in Barsel. In addition the district also has significant coal reserves. ${ }^{9}$ With such a significant area of the district inundated, Barsel's also has potential for fisheries development. However, besides some traditional fishponds in the peat swamps of the south, to date fish are mostly caught rather than cultivated.

\subsection{FORESTRY}

As in other areas of Indonesia, the New Order government classified most of the district as state-controlled 'Forest Estate' (Kawasan Hutan) and allocated large forested areas to commercial logging companies (Barber et al. 1994; Peluso 1992). Originally nine timber concessions (Hak Pengusahaan Hutan or HPH) were active in Barsel. However, when the terms of four of these concessions expired during the 1990 s, the state-owned forestry company Inhutani III obtained rights over areas that had earlier been allocated to private timber companies (see Table 1). One of these areas was subsequently returned to the Ministry of Forestry and Estate Crops (Departemen Kehutanan dan Perkebunan or Dephutbun) and the status of the two other areas seems to be still under review. This left Inhutani III unambiguously active in only one area.

According to information from the Provincial Forestry Service (Dinas Kehutanan Tingkat I), only four HPHs have recently been active in Barito Selatan. While two concessions were extended in 1999, another two concessions expired in the mid 2000 (see Table 1). These concessions now operate primarily in the remoter highland areas close to the borders with Barito Utara (to the north) and South Kalimantan (to the west). According to information from the Provincial Forestry Service, of these four logging concessions two expired in mid 2000 and two were extended last year (see Table 1). 
Table 1. The Status of Timber Concessions in Barito Selatan

\begin{tabular}{lcl}
\hline Name of Company & $\begin{array}{c}\text { Extent of Area } \\
\text { in Barsel (ha) }\end{array}$ & Status of Concession \\
\hline 1. PT Sindo Lumber & 48,000 & Already renewed \\
2. PT Indexim Utama Corp & 52,480 & Renewed 30 Sept. 1999 \\
3. PT Sinar Barito Indah Plywood & 25,000 & Expired 5 May 2000 \\
4. PT Tiga Badang Sanak & 107,000 & Expired 7 April 2000 \\
5. PT Hasnur Jaya Utama & 38,445 & Granted 14 Oct. 1999 \\
6. PT Inhutani III & 100,000 & Granted to Inhutani III April 1995 \\
(ex PT Palangka Nusantara) & & \\
7. PT Inhutani III & 217,500 & Status unclear \\
(ex PT Djayanti Djaya I) & 58,850 & Surrendered to Dephutbun. \\
8. PT Inhutani III (ex PT. Guntur Gempita) & - & Status unclear \\
9. PT Inhutani III (ex PT Rimbayu Barito) & \\
10. PT Perwata Rimba/ & & Active \\
PT Sindo Lumber (HTI Trans) & 21,850 & \\
\hline
\end{tabular}

Source: Dinas Kehutanan Tk I.

In 1999 Dephutbun also granted a new HPH concession over part of one of the expired concessions. ${ }^{11}$ According to one report, PT Tanjung Lingga (renowned for its activities around Tanjung Puting National Park) is now also working part of a third Inhutani III area. ${ }^{12}$

In addition to these large-scale operations, two timber companies together operate a 'HTI-trans' project - an industrial timber estate (Hutan Tanaman Industri or HTI) involving 200 transmigrant households (Pemerintah Kabupaten Barito Selatan 1999b). ${ }^{13}$ The Branch Office of the Provincial Forestry Service in Barito Hilir (Cabang Dinas Kehutanan [CDK] Barito Hilir) also reported that there were two areas with wood utilization permits (Ijin Pemanfaatan Kayu or IPK to clear the land in Barito Selatan and 9 sawmills with valid permits to process timber (Dinas Kehutanan Cabang Dinas Kehutanan Barito Hilir 2000). ${ }^{14}$

Since the twilight years of the New Order regime, Indonesia's forestry laws have been in a constant state of revision, and many of these initiatives ostensibly offered new actors opportunities to benefit from concession operation. For instance, under the transitional Habibie government, the Minister of Forestry and Estate Crops created policy initiatives to grant opportunities in the forestry sector to small and medium size businesses as well as local communities. ${ }^{15}$ To this end the Minister issued a number of decisions generating new opportunities for co-operatives to participate in $\mathrm{HPH}$ operations in various ways. According to one decision (Kepmen No 732/Kpts-II/1998), HPH-holders wishing to renew their concessions were required to initially allocate $10 \%$ of their shares to cooperatives with sequential grants every year. HPHs in Barsel responded by forming cooperatives. For instance, PT. Sindo Lumber has sold shares and given dividends to the cooperative Sindo Sejahtera. According to an official in the Dinas Koperasi, since the inception of this decision each year PT Sindo Lumber grants a dividend of some Rp 28 million to the cooperative which involves around two hundred company workers and former workers. ${ }^{16}$ Another cooperative, Perwata Lestari, has also been formed to transport and supply oil to another company associated with PT Sindo Lumber. A third cooperative, Tabah Swarga, operates by buying timber from a neighbouring logging concession. However, 'in other cases', the informant said, 'although the HPHs have base camps here, they have cooperatives in Banjarmasin' ${ }^{17}$ Under such initiatives, it seemed unlikely that surrounding communities had benefited to a significant extent.

Under the former Minister of Forestry and Estate Crops, Muslimin Nasution, other initiatives 
encouraged community groups to form cooperatives to obtain thirty-five year 'community forestry leases' (Hak Pengusahan Hutan Kemasyarakatan or HPHKM) or one year 'forest product harvest concessions' (Hak Pemungutan Hasil Hutan or HPHH). In late 1999, the new Minister suspended these initiatives. However, in the meantime three permits were processed in the names of cooperatives - two for IPK clearance permits and a third for a HPHKM community forest lease. A cooperative known as Karya Tani had already obtained land and (in July 2000) had allegedly started operations. However, well connected vested interests in the district were playing key roles in at least some of these enterprises. For instance, district government officials were said to be behind a cooperative that had requested an IPK but had not yet begun operations. A key forestry official, the head of the Dinas Perhutanan dan Konservasi Tanah (PKT), reportedly was the head of this cooperative, which also involved the director of the district government-owned company (Badan Usaha Milik Daerah or BUMD), PD Danum Belum, as one of its members. ${ }^{18}$ These developments suggested that those with close ties to key officials who have critical information or decision-making roles and those who occupy strategic positions within the district (either formal or informal) were most likely to profit from new policy initiatives in the forestry sector. As other studies of forestry outcomes at the district level have indicated, exchanges and accommodations between key actors at the district level continued to play a key role in forest outcomes (McCarthy 2000b).

As in other areas of Indonesia, especially since 1997, forestry regulations have not been regularly enforced. As a consequence, there are hundreds of unauthorized sawmills operating outside of the legal framework around South Barito. While no figures are at hand regarding the scope of this activity in Barsel, signs of the industry area can be found in many places. For example, in the swamps down the Barito river (Jenamas subdistrict), sawmills stand on the both banks of the river in untidy rows. ${ }^{19}$ Piles of off cuts litter the banks, while large stacks of sawn timber sit waiting to be loaded onto traditional wooden Madurese craft and a few more modern vessels to be shipped to Java, Malaysia or beyond. The head of the local military command (Komando Distrik Militer or Kodim) reported that a few months ago there were approximately 40 bandsaws and 2 sawmills operating. ${ }^{20}$ Another source reported that recently there had been some 63 bandsaws operating here, and it is possible that there are more. ${ }^{21}$ The bandsaws had started operating here during the PLG period when - in the process of clearing the forest for the mega-rice project - many IPK timber clearing licenses were issued. Although these licenses had subsequently been revoked after the cancellation of PLG, the sawmills have continued to operate. Only around 17 of these were said to have licenses, mostly for working with processed timber - for instance, to produce moulding or dowling from semi-processed wood - rather than for cutting logs into planks. ${ }^{22}$ When the Barito River is high, loggers float rafts of logs from further up river - including from the neighbouring district of Barito Utara - down to the sawmills here. Jenamas's sawmills occupy a strategic position: as this is the last place for wood to be processed before proceeding to South Kalimantan, it is a convenient stopping off point for loggers. Moreover, the town can only be reached by boat - and since most traffic now uses the road - Jenamas constitutes a discrete centre for extra-legal timber production. 


\section{DECENTRALISATION IN BARITO SELATAN}

\subsection{THE FINANCIAL SITUATION}

According to Indonesia's main decentralisation laws (Undang-undang No 22/1999 and Undangundang No 25/1999), the autonomous districts and municipalities must necessarily take responsibilities for a much larger range of government functions. However, as in other areas of Indonesia in the context of implementing the two decentralisation laws, a primary concern amongst district government decision-makers is the capacity of the district to support itself as an autonomous region. In other words, district government planners have to find the revenue to support these expanded functions. Clearly forestry related issues need to be discussed in this context. Therefore, before proceeding further, it is important to consider the district budget.
Tables 2 and 3 demonstrate a number of challenges facing Barsel before the implementation of the decentralisation laws, including:

- Barsel is heavily dependent on 'assistance and contributions' (sumbangan dan bantuan) from central and provincial governments. This assistance amounts to $62 \%$ of the total district income.

- Regionally-generated income (Pendapatan Asli Daerah or PAD) sourced from within the district itself constitutes its own discrete category in the district budget. Barsel's PAD amounts to less than Rp 2 billion or $2 \%$ of total district receipts.

- The forest product royalty (Iuran Hasil Hutan or IHH) and land and building tax

Table 2. Summary of District Budget, Fiscal Year 1999-2000. ${ }^{23}$

\begin{tabular}{lr}
\hline Total District Income (Jumlah Penerimaan) $^{24}$ & $87,925,000,000$ \\
\hline Regionally-Generated Income (Pendapatan Asli Daerah) & $1,751,000,000$ \\
Regional Taxes (Pajak Daerah) & $210,000,000$ \\
Regional Charges (Retribusi Daerah) & $568,000,000$ \\
Tax Receipts (Hasil Pajak) & $19,365,000,000$ \\
$\quad$ Land and Building Tax (Pajak Bumi dan Bangunan or PBB) & $18,793,000,000$ \\
Non-Tax Receipts (Hasil Bukan Pajak) & $1,464,000,000$ \\
$\quad$ Forest Product Royalty (Iuran Hasil Hutan or IHH) & $1,263,000,000$ \\
Assistance and Contributions (Sumbangan dan Bantuan) & $54,790,000,000$ \\
\hline Expenses (Pengeluaran) & $83,918,000,000$ \\
\hline Routine Spending (Pengeluaran Rutin) & $46,767,000,000$ \\
$\quad$ Development Expenditure (Pengeluaran Pembangunan) & $31,592,000,000$ \\
\hline
\end{tabular}

Source: Daftar K-2 Statistik Keuangan Pemerintah Daerah Tingkat II 1999/2000. 
Table 3. Summary of Regionally-Generated Income (Pendapatan Asli Daerah): Target for $2000^{25}$ (Rupiah)

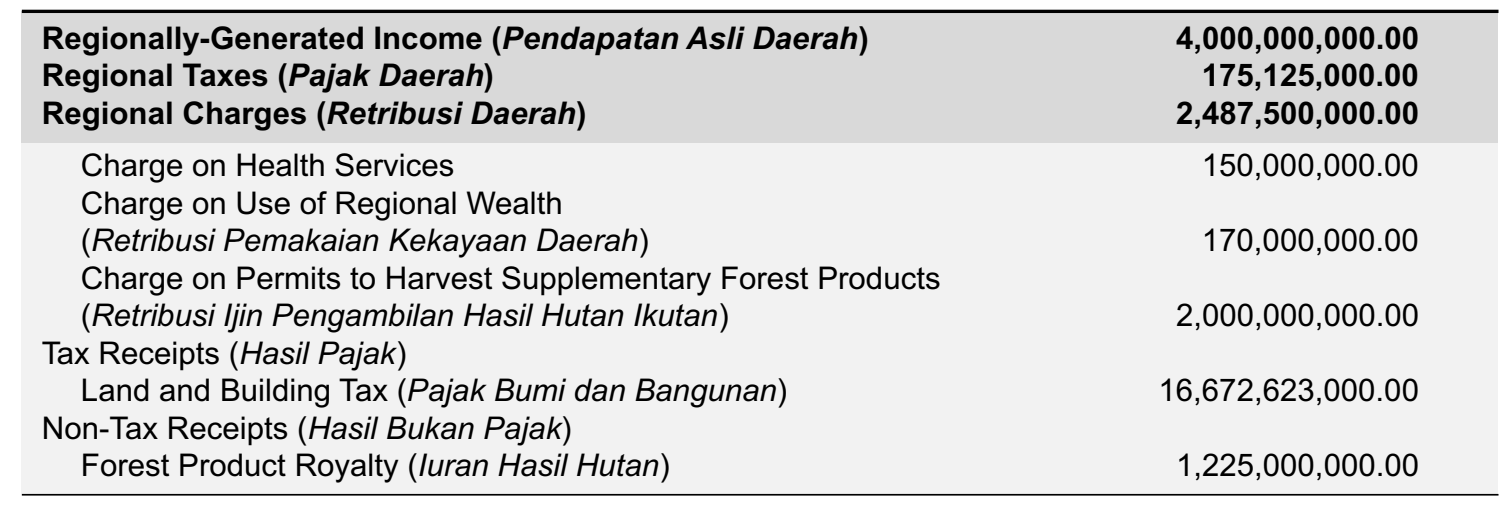

Source: Dispenda, Pemda Barsel.

(Pajak Bumi dan Bangunan or PBB) are the budget items that contain the contributions from logging concessions to the district budget. ${ }^{26}$ Even taken together these are very small, contributing only $2.2 \%$ to the district budget.

This indicates that, while the district government faces the challenge of generating sufficient budgets to support their autonomous functions, Barsel is starting with a low revenue base. Consequently, even if Barsel were to obtain substantially greater amounts of rent accruing from logging operations after regional autonomy, the district would still remain heavily dependent on central government receipts. While at the time of the research, the size of central government allocations under regional autonomy remained uncertain, the concern was that if they declined too severely, the district could face a fiscal crisis. ${ }^{27}$ In this context, the Barsel government needed to consider carefully the revenue that it can generate itself, including through exploiting the district's forests. Because the investments are low and the rents are high compared with most other activities, enterprises that exploited local forests appeared to be the easiest and most obvious place to begin generating revenue. ${ }^{28}$

Interviews with decision-makers in Buntok revealed that district government decisionmakers have indeed zealously pursued the goal of generating PAD. Allocations from the central government have already fallen, and the district government aims to minimise the problems that this is creating. Although there are no precise figures for the decrease, an official from the district planning office (BAPPEDA) noted that the public works budget for roads in the district had fallen from 6 billion rupiah a few years ago to 2 billion rupiah this year. It costs around 6 billion per month to just pay for public servants, he observed. If we don't have more revenue, it will be difficult to get regional autonomy to work. ${ }^{29}$

Many others in the district were not optimistic about the budgetary situation after the implementation of regional autonomy. Popo Madjen, an adviser to the district DPRD, noted that after regional autonomy the region will receive two kinds of allocation: a 'general allocation' (dana alokasi umum) and a special allocation (dana alokasi khusus). Noting that the formula for evaluating the 'general allocation' from the central government will still give weight to population in a district, he argued that Barsel will probably fail to receive a sufficiently large 'general allocation', as the district has a comparatively small population. ${ }^{30}$ At the same time, the 'special allocation' will depend on government priorities and the comparative needs of other regions. Therefore, Barsel may not receive a significant 'special allocation' every year. 'In this situation', he concluded, 'it is not possible to be optimistic [about Barsel's budgetary situation]'. ${ }^{31}$ 
The head of Barsel's District Revenue Office (Dinas Pendapatan Daerah or Dispenda) reported that in 2000 the district government set a target for PAD of 4 billion rupiah (see Table 3). He noted that there are estimates that over the long term ideally each district needs to obtain a minimum of 10 billion rupiah for regional autonomy. 'If Law No 22 is implemented well,' he said, 'we should be able to reach this target'. ${ }^{32}$ In the meantime the target of 4 billion rupiah represents an increase in PAD of $228 \%$. To reach this target, the district government aims to increase regional charges (retribusi daerah) by some $438 \%$ in just one year. As later discussion will show, this forms the background for the district government policies in a range of areas, including district management of illegal logging and new district enterprises that aim to generate revenue from timber.

There has been a wide-ranging discussion concerning how PAD can be increased. When the district government considered placing a new tariff on electricity bills, public disapproval prevented this. Nonetheless, with the agreement of DPRD, the district government has imposed a 'Charge on Health Services', in effect increasing hospital bills by $300 \%$. Hospital staff have to levy the fee on patients and cashstrapped local people trying to attend to illnesses of family members at Buntok's hospital. A member of the hospital staff related that the change has proved to be very controversial amongst staff working at the hospital member. Staff faced a difficult issue: how would they ask a patient about their ability to pay before offering treatment? ${ }^{33}$

\subsection{CREATING A DISTRICT CORPORATION}

The district government has passed another regulation (Perda No 6/2000) providing for the operations of a district government owned company (Badan Usaha Milik Daerah or BUMD). ${ }^{34}$ This BUMD - known as PD
Danum Belum - will conduct business on behalf of the district and thereby raise funds for the district. Although other districts are now following Buntok's lead, this BUMD is the first formed at the district level in Central Kalimantan. It has recently moved into a new office in Buntok and will become active in October. Eventually it is envisaged that the BUMD will have its own subsidiary companies active in the services, construction, mining, plantations and forestry sectors. The district government has set a goal for the BUMD of generating Rp 100 million in revenue during its first year of operation. The director of the BUMD said that over the longer term BUMD wants to become involved in mining. However this will take considerable investment and time. In the short term PD Danum Belum will concentrate its activities in the forestry sector. Given the district's abundance of forest resources and the comparative ease of extracting timber under the new decentralisation regulations, district decision-makers see the forestry sector as the area to begin BUMD activities. ${ }^{35}$

To this end PD Danum Belum needed to obtain legal rights over areas of forest. To begin, PD Danum Belum wished to generate operating capital by obtaining IPK timber clearance permits to fell the forest and ostensibly open up plantations.

However, the company faced the problem of obtaining access to local forest resources. All the forest areas at hand were former concession areas and had already been logged. At that point national laws placed areas within the 'Forest Estate' under the control of the Ministry of Forestry and Estate Crops. Although information about their exact status was difficult to obtain, apparently, these lands were either under long term leases to logging concessionaries or in the control of Inhutani III. Moreover, after the Ministry of Forestry and Estate Crops suspended the Government Regulation 6 of 1999 (Peraturan Pemerintah No 6/1999) that provided for HPHH, the district 
government had neither the authority to allocate areas within the 'Forest Estate' to the BUMD nor the capital or political connections to obtain a HPH. ${ }^{36}$

Consequently, the creation of a viable BUMD entailed obtaining property rights over government-controlled forest estate from the state-owned forestry enterprise, Inhutani III. To facilitate this, Barsel's incipient BUMD wrote to the director of Inhutani III requesting the granting of land for an IPK permit. The director argued that the local people - as the rightful 'landlord' (tuan rumah) of the area - have a greater right to the land than Inhutani III who, although they have a mandate to rehabilitate former concession areas, continued to exploit them. ${ }^{37}$ To further this request, the director travelled to Jakarta to lobby the Directorate General of Production within the Ministry of Forestry and Estate Crops. After initially meeting resistance from Inhutani III, the stateowned company finally allowed an area to be granted to BUMD for an IPK. ${ }^{38}$

With the support of the Bupati, PD Danum Belum had requested a second IPK clearance permit for 1,720 ha over an area to be cleared for a planned transmigration scheme, an area controlled by PT Inhutani III. ${ }^{39}$ According to an article in the press, the Ministry of Forestry and Estate Crops had agreed to issue an IPK forest clearance permit to open a transmigration settlement here. ${ }^{40}$ However, an earlier decision of the Ministry of Forestry and Estate Crops (SK Menhutbun No 227/Kpts-II/1998) gave BUMN priority for an IPK granted in $\mathrm{HPH}$ areas that have either expired and not been extended or reallocated. The caveat being that 'the holder of the IPK foster small and medium size enterprises and cooperatives together with the community living around the IPK concerned' (Telescope 2000). Accordingly, the Ministry gave priority to Inhutani III over PD Danum Belum. However, as an article in the Central Kalimantan tabloid Telescope suggests, as the presence of Inhutani III was already much resented, this decision added insult to injury.
PT Inhutani III has already moved far from its main mission - conservation and forest rehabilitation. The proof is that in fact this state company ostensibly only operates as a broker who takes HPH concessions whose permits have expired and then sells them back to private parties who are able to buy them at a prearranged price. Evidently the old paradigm still holds at PT Inhutani III. They feel the centre has the right to drain (menguras) the wealth of the region and they do not feel that they need to give the IPK to BUMD in the region (Telescope 2000).

The article concluded by recommending that the district government take strong actions against a company 'that lacks a vision that supports regional development'. 'If need be', the authors suggested, the government might follow the example of the Riau regional government 'which has brought sanctions against Inhutani III' (Telescope 2000).

The Ministry of Forestry and Estate Crops issues IPK over forest areas to parties intending to clear land for plantations. Informants in Central Kalimantan noted that many parties have obtained IPK, at least nominally to develop a plantation, however, after harvesting the timber, they never subsequently plant plantation crops. According to a BUMD official, PD Danum Belum is considering plans to replant the IPK with productive plantation trees such as rubber or candlenuts (kemiri). However, it is still unclear how successful this will be. One of the problems the local government faces in this endeavour is a critical lack of plantation expertise. According to the head of the BUMD planning is made difficult because of the lack of technical knowledge in local government, for instance regarding the suitability of local soils for various plantation crops. A second problem the BUMD faces in moving in this direction is that of selling plantation crops not widely grown in a place far removed from agricultural markets. A major 
challenge in his view is 'avoiding a crisis of confidence... the important thing is to begin' ${ }^{41}$ A third major limitation facing the BUMD was a lack of start up capital.

\subsection{TOWARDS A DISTRICT TIMBER REGIME}

Violation of the government's laws and regulations on timber extraction has clearly taken place for some years in Barsel. Yet, as noted earlier, across Indonesia the enforcement of existing regulations has declined over the previous few years and uncontrolled logging has taken on a life of its own (McCarthy 2000b). According to one informant in Barsel, this informal industry began to boom over 1997-98. During the election of 1997, the local branch of the ruling Golkar party needed to obtain funds for its campaign and was eager to seek opportunities. In return for donations to party funds, officials relaxed government attempts to control illegal logging in Barsel..$^{42}$ At this time, with accelerating inflation, many people faced a livelihood crisis. During the monetary crisis, as the rupiah's value fell, the price of timber increased in rupiah terms. With a crisis in legitimacy for the regulatory regime, it became increasingly difficult to implement government regulations. Subsequently, greater demand coupled with the relaxation of law enforcement, helping to stimulate an explosion in illegal logging. ${ }^{43}$ In the past many local people had watched logging concessions controlled by outside interests reap the benefits of the concessionaire system. While logging operations had carefully worked with a semblance of legality, now as illegal operations extended, this was less necessary. As others saw this occurring, they joined in, and loggers began to work completely outside the legal regime. While in many areas logging operations had taken the most valuable large timber, there were significant strands of less valuable varieties left. As timber demand stayed high, logs that previously had little value now became worth extracting. In this way, as elsewhere, the informal industry became as important as the formal one. ${ }^{44}$

Previously the district government (Pemerintah Daerah or Pemda) had not developed the capacity to effectively impose taxes on timber and ended up watching timber leave the area without levying district taxes. Now, regional autonomy and falling allocations from the centre have created the stimulus to raise as much PAD as possible. Therefore, following a similar initiatives in Sampit, in May 2000, with the agreement of the DPRD, the Bupati passed a new regulation (Perda No 2/2000) that allowed for the levying of a new charge on the harvesting of forest products (retribusi pemgambilan hasil hutan ikutan). ${ }^{45}$ This initiative aimed to tax all forest and plantation products that leave the area. Taxes were to levied on all forest and plantation products ranging from rubber, rattan, honey to gaharu, damar and bamboo. However, at the point research was conducted for this study, fire wood, research materials and the production from logging concessions (HPHs and HPHHs) are except from the retribusi. District officials considered these later activities to be already subject to the central government's control and to fall within the existing taxation regime. ${ }^{46}$

In 2000, when the field work for this study was conducted, the forestry office in Buntok (CDK Barito Hilir) remained a branch office (cabang) under the authority of the Provincial Forestry Service (Dinas Kehutanan Tingkat I). At that time, it was expected that with the implementation of Indonesia's regional autonomy law, the Kanwil and Dinas Kehutanan Tingkat $I$ at the provincial level would be amalgamated, and the Cabang Dinas Kehutanan would become a Dinas Kehutanan in its own right at the district level - under the direct authority of the Bupati. Although in May 2000 the district government had passed a regulation regarding the structure of the new (autonomous district level) Dinas (Perda No 7/2000), this regulation could not be implemented until the formal inception of regional autonomy in 2001. This meant that to implement the new regulation 
regarding the retribusi, the Bupati still needed to coordinate with the Governor, the Ministry of Forestry's Regional Office (Kantor Wilayah Kehutanan or Kanwil) and the Branch Office of the Provincial Forestry Service (Cabang Dinas Kehutanan) (Kalteng Pos 2000).

As touched upon earlier, during 2000 the policy framework regarding the legal authority and administrative roles of different government agencies was in a state of flux, creating a great deal of uncertainty. In this context, given the need for districts to stabilize their revenue bases, there were both opportunities and incentives for districts to take initiatives of varying degrees of legal validity to secure new sources of funds. Yet, in contrast to neighbouring Kapuas district, the Bupati in Barsel has not attempted to raise revenue through granting small HPHH concessions to local actors (see Kapuas case study). In late 1999 the Ministry of Forestry and Estate Crops suspended the HPHH small concession initiative and the provincial Dinas, and accordingly the CDK forestry office in Buntok followed this policy. Moreover, at the time when this decision was taken, the head of the CDK in Buntok had a close personal relationship with the current Bupati, and the Bupati followed his advice on this matter. ${ }^{47}$ Accordingly, in consultation with forestry officials at the provincial level, the CDK has decided to follow the retribusi option pioneered bythe district in Kotawaringin Timur. As we will see, this has proved to be lucrative strategy for the district finances.

Following a meeting of the district council (Muspida), in May 2000 the Bupati formed a district level team for handling illegal timber and collecting the retribusi ${ }^{48}$ In nine days this team encountered more than 20 timber rafts on the Barito River. The team 'processed' what amounted to some $30,839 \mathrm{~m}^{3}$ of timber according to the new regulation. Those in possession of the wood had to pay the taxes and charges - including IHH (now called Provisi Sumber Daya Hutan or PSDH) and reforestation fund (Dana Reboisasi or DR) to the central government and the new retribusi to the local government. ${ }^{49}$ This operation generated DR of Rp 5,049,799,085 and PSDH revenues of Rp $2,189,673,823$. The operation also collected $\mathrm{Rp}$ $1,769,522,400$ in retribusi for the local government treasury (Kalteng Pos 2000). As Table 3 indicated, the district government had earlier forecast that this newly introduced retribusi on timber production from Barsel's forests would yield Rp 2 billion over the year. Now, after this unexpected windfall, the Bupati hoped that in less than a year Barsel would reach the Rp 4 billion target (Banjarmasin Post 2000d). As most of this timber had 'run' from Barito Utara district, this neighbouring district subsequently developed a similar regime.

Yet, apart from this temporary operation, the Bupati needed to establish routine procedures for collecting the charge. To this end the Bupati issued an instruction to district government agencies regarding how the tax should be collected. Henceforth, teams collecting this tax would operate under the authority of the Camat in each subdistrict. An institutionalised committee that includes the Camat and the subdistrict military and police chiefs, the Muspika, in coordination with district forestry agencies would oversee the teams. ${ }^{51}$ Each subdistrict team will operate posts on the rivers and the highway that will collect the fee, and each team is obliged to report weekly to the district Dispenda. ${ }^{51}$

Previously, the police were authorised to bring sanctions against those infringing regulations of the central government, including those related to timber. Accordingly, the police had played the primary role in processing illegal timber. Treating illegally obtained $\log s$ as 'captured timber' (kayu tangkapan), the police confiscated and auctioned it. According to a military official interviewed in the course of this study, they liked this system 'because for sure there were a few open doors.' ${ }^{52}$ In other words, the police enjoyed ample opportunities to profit by acting beyond their legal responsibilities. For example, it is an open secret that they could find ways to 
make profits by underestimating the amount of timber confiscated or by selling it on at lower than the market price. Or perhaps they could enter into arrangements with loggers, allowing illegal timber to pass after payment of extra-legal fees. However, under the new system the timber would no longer be subject to the legal process, confiscated and auctioned. Rather, the timber would be 'processed' as 'found timber' (kayu temuan), and according to the new regulation subject to district retribusi. In other words, attention would be paid to whether the timber had been subject to taxes rather than whether it had been harvested legally.

This new system created controversy across Central Kalimantan and beyond. The Ministry of Forestry and Estate Crops pointed out that according to law on fiscal balancing (UU No 25/ 1999), $80 \%$ of timber revenues collected by the national government were returned to the region of origin. The possibility emerged, he noted, that timber interests would use this new retribusi smaller than the DR and PSDH - to avoid these other larger taxes. After paying this tax, they would then take it that their timber now had a legal status and could be exported to other regions. While the new charge raised revenue successfully for the regions, it was feared that it authorised illegally harvested timber. ${ }^{53}$ Yet, at least in this district the potential for conflict with the central government over this issue was diffused: in Buntok those levying the new retribusi on illegal timber were also collecting the existing government timber royalties and fees (DR and PSDH) in accordance with national law.

However, district police were less than enthusiastic about this new procedure for dealing with illegal timber. ${ }^{54}$ According to a senior military officer, this lack of enthusiasm coalesced with somewhat of a tussle over institutional status. This dispute reflected the vested interests of the different actors involved and the lack of clarity regarding roles and responsibilities. During the New Order, the police had been part of the armed forces. Now, although the police formally fell under the
Ministry of Defence, they were no longer a part of the Indonesian Armed Forces (Tentara Nasional Indonesia or TNI). Yet, there has been some discussion at the national level of placing responsibility for the police under a special police minister or even with the Ministry of Internal Affairs. If the later were to occur, at the district level the police could find themselves under the authority of the Bupati. Consequently, the problem of how timber will be handled was also one of wider institutional power. Will the police bow to the authority of the district government and 'process' timber (as kayu temuan)? Or, for the sake of implementing national legislation, will they continue to treat timber cut and transported outside the legal regime as 'captured timber' (kayu tangkapan)? If discussions with a district military official were any indication, the local military command favoured the first option: while the police were less happy, the military appeared to be sanguine with the way the new retribusi would operate. According to this informant, however, there was still a question: how helpful would the district level police (Polisi Sektor or Polsek) be in implementing the new retribusi. ${ }^{55}$ In the short term, by implementing the regulation through Muspika and via new teams involving the police, the Bupati had ensured that the police acceded to the consensus amongst decision makers at the district level.

The lack of clarity regarding the legal and administrative roles and responsibilities of different government agencies were also leading to confusion and disputes over jurisdiction in other areas. In July, forestry officials from Barito Utara (Barut) chased three rafts of illegal timber down the Barito. The timber was finally apprehended on the Barito River within Barsel. At the time of the field research in July 2000 forestry officials from Barito Utara were guarding these three rafts on the river just south of Buntok. In order to work out an agreement about how to process the timber - including which district should obtain the retribusi on the timber - according to an informant in the CDK Barito Hilir, the two Bupati is needed to consult. 
'If they want to process it quickly,' a CDK official said, 'they need to surrender it to be processed here in Barito Selatan. ${ }^{56}$ On August 18, 2000, the Banjarmasin Post reported that to date the two districts had failed to come to an agreement. The Barut authorities demanded that the timber be returned for processing in Barut. However, the Barsel authorities argued that, although the timber originated in Barut, as it had been apprehended in Basel, Barsel authorities should process the case.

Meanwhile the entrepreneur who owned the timber worried about the timber deteriorating. According to the Banjarmasin Post, the entrepreneur preferred to process the case in Barsel. While in Barut they would have to pay a tactical fee (dana taktis) of $\mathrm{Rp} 50,000 / \mathrm{m}^{3}$, in Barsel the entrepreneur would only be obliged to pay the retribusi. Meanwhile the Governor of Central Kalimantan advised that the case be processed as quickly as possible without paying attention to who owns the timber. ${ }^{57}$ According to Popo Madjen, a prominent Buntok intellectual, the danger was that these cases were setting a precedent for loggers working outside the legal regime: simply by floating their timber downstream - and (if they are caught) by processing permits and paying their tax dues there - they will be able to obtain official documentation for their operations. ${ }^{58}$

On July 2, 2000 the district government invited all actors with timber operations - legal or illegal - to a meeting in Buntok. The purpose was to 'socialise' the new regulation. Although there are no precise figures on the number of those present, according to one of those who attended it, it was a packed meeting. The occurrence of this meeting indicated that the district administration had knowledge of all the people active in extra-legal logging. Although it is often claimed that it is impossible to regulate illegal logging, this pointed to the likelihood that - if it was politically feasible and seen to be in the interests of the district - some form of control might indeed be possible.
However, rapidly changing policies, inconsistent law enforcement and unclear roles and responsibilities of different government agencies created a great deal of uncertainty. This could only generate a perception of risk for those engaged in extracting timber from the district's forests. Consequently, the incentives favoured rapid liquidation of resources where the rational logger, legal or illegal, would cut as much as they could as fast as they could, without regard for future options. ${ }^{59}$

\subsection{DECENTRALISATION, SPATIAL PLANNING AND ENVIRONMENTAL MANAGEMENT}

In general terms the Regional Development Planning Agency (BAPPEDA) completed a regional spatial plan for the district (Rencana Tata Ruang Wilayah Kabupaten or RTRWK) in 1993. However, the BAPPEDA has only been able to carry out a more technical and detailed plan (rencana detail) in a few areas. In the meantime, the central government went ahead with the PLG million hectare peatlands project, a project that did not fit in with the pre-existing RTRWK. Consequently, BAPPEDA had to revise the RTRWK to incorporate PLG. In addition, the Ministry of Forestry and the Provincial Government have engaged in the integration process (Paduserasi) to sort out discrepancies between the provincial spatial plan and the Ministry of Forestry's forest planning (TGHK). Although an earlier draft of a new integrated spatial plan appeared to be close to completion in April, 2000, a meeting in the provincial capital in June indicated that the Paduserasi process had not yet been completed. At the time of this research, BAPPEDA's district office was awaiting the finalisation of this process before revising the RTRWK to incorporate changes from above. ${ }^{60}$

In short, the formal spatial planning process has been slow to decentralize. According to another official in BAPPEDA, "the problem is that the 
centre has too many agendas - mining, forestry, plantations - that all depend upon land. Consequently the permit comes down from the centre without looking at the situation in the region'. ${ }^{61}$ If the spatial plan is to reflect more accurately local priorities and field realities, regional planning officials argue that the district level must have a primary role in creating the plan. A BAPPEDA official envisaged that the provincial spatial plan will later need to be revised to take into account the district spatial planning now being done on a finer scale. In the meantime, the Ministry of Forestry has continued to allocate areas of forest for use without consulting BAPPEDA or even letting the office know. For instance, logging concessions and forest conversion permits have continued to be issued or renewed without taking into account district spatial plans. In at least one case the Ministry of Forestry in Jakarta has issued permits for concessions that have even overlapped provincial boundaries. In other cases, logging concessions still contain steep areas that - according to the RTRWK - should be excluded as 'protected areas'.

At the national level, the National Planning Agency (BAPPENAS) in collaboration with the Ministry of Internal Affairs is discussing these problems. A BAPPEDA official interviewed in Buntok argues that if the power to make decisions is not granted to the regions, the district government should have discretionary powers. For example, the central government could retain power to grant permits, but this would be based on recommendations from the district. Ideally there would be a balance between the central and regional governments. For example, if a planned development does not fit with the spatial plan, the district government would have the right to turn it down. 'Now', this official noted, 'the centre issues permits, but it is the district that feels the consequences' ${ }^{62}$

Within the district itself, BAPPEDA planners have also faced the problem that the RTRWK has not been sufficiently integrated into the way decisions are made. According to one
BAPPEDA official, this is because the RTRWK is insufficiently understood in decision making circles. Consequently, new industries have been located in the wrong areas. ${ }^{63}$ For example, Bapedalda officials regret that a rubber factory has been constructed next to the Barito River in a residential zone and with the possibility of industrial waste entering the Barito River. Local decision-makers insufficiently take the RTRWK into account when making decisions. Moreover, apparently there is a lack of understanding by regulatory instruments to make sure the RTRWK is followed in decision making. To overcome this problem BAPPEDA is working on three new district regulations that require district decision making to follow the district's spatial plan.

According to the head of the Organisation Section in Regional Environmental Protection Agency (Bapedalda) in Palangkaraya, with regional autonomy the State Ministry for the Environment is implementing a new initiative for environmental management at the district level. Following the new environmental law of 1997 (UU No 23/1997), the national government has issued a regulation (PP No 27/ 1999) regarding environmental management, which was implemented in October 2000. This regulation allows for the formation of environmental impact assessment commissions (komisi amdal) in the districts. According to this new initiative, an environmental impact assessment will be required before new logging concessions, exploitation or conversion permits or even HPHH are issued. The Regional Environmental Protection Agency formed in the districts will facilitate sessions of district komisi amdal that will consider the physical and social implications of planned decisions. These sessions will give the opportunity for village heads, subdistrict heads (Camat), NGOs and community groups to directly express their opinions regarding planned developments. In making a decision or recommendation regarding such a licence, higher government authorities (such as the Governor) will consider the judgment from the komisi amdal. An official in 
Bapedalda recognised a critical problem: the initiative may be 'too slow' because the 'regions are not yet ready'. In mid-2000, the central government was considering issuing 25 new logging concessions in Central Kalimantan, and it is possible that these concessions could be issued before the komisi amdal are operative. ${ }^{64}$ There is still a question of to what extent this amdal can influence decisions: in the past recommendations based on environmental considerations have not been followed, demonstrating that, as the State Ministry of Environment can only make recommendations, it lacks the capacity to affect decisions made by other departments.

In April 2000 the Bapedalda opened its new district office in Buntok. When field work for this study was conducted the following July, the new office still lacked a director: it had only a secretary and four staff. There was also a need for funding and basic office and laboratory facilities. As the actors operate within the district, it is important to carry out investigations at this level. ${ }^{65}$ However, the balance of power regarding the issuing of permits, monitoring and sanctioning still rests with the provincial and central government authorities. Even if some of these powers are transferred to the districts, there remains a question of how powerful Bapedalda will be compared to executing or decision making agencies even at the district level.

\subsection{TRENDS SHAPING THE IMPACT OF REGIONAL AUTONOMY IN BARSEL}

Several informants reported that the district faced a critical problem - a lack of capacity amongst district officials and members of the district assembly preparing for regional autonomy. People generally discussed this issue in terms of 'poor human resources' (sumber daya manusia yang lemah). When asked to specify what this meant, a critical official said that many members of the district assembly had very little formal education, with many having only completed primary school. He argued that most decision-makers had a long schooling in the culture of the New Order - where decisions were made from above and implemented below. The implication was that this had stifled the readiness of lower level staff to take the initiative.

The irony of the situation was that, to implement regional autonomy, senior officials spent a great deal of time in Jakarta obtaining instructions about how they should proceed. The problem manifested itself as a lack of ability to think systematically and to formulate solutions: 'people are good at talking,' he said, 'but weak on solutions'.

A member of a local NGO described a lack of consciousness regarding environment issues. With respect to forest management, district officials and decision-makers concentrated on the issue of exploitation: how district forests could be exploited to support the regional autonomy. Few decision-makers seemed concerned about the long-term ecological consequences of over-exploitation. Yet debate at the district level regarding how the district should arrange their affairs for the longer term has only begun. The discussion regarding the district's environmental future appeared to be a discussion that was yet to take place. It remained unclear how or when this might begin - or whether it would occur in time to sustain any significant portion of Barsel's already degraded forests.

On a more optimistic note, the head of the Provincial Forestry Service compared regional autonomy to the process that took place when Central Kalimantan obtained provincial status. At first there was very little capacity within the province. In the $1950 \mathrm{~s}$, Palangkaraya was created on the site of a village. Yet, eventually Central Kalimantan became an autonomous province and Palangkaraya a city in its own right. He compared regional autonomy to a 
learning process: 'when someone goes to school, they can't get 10 all the time. They will learn through the process. ${ }^{96}$

In Jakarta critics have argued that the new initiatives will displace corruption from the centre down to the district level (Lay 1999; McCarthy 2000a). However, a senior BAPPEDA planning official in in Barsel argued that if more decision making power over forestry was devolved, regulation at that district level could make the timber industry more transparent. Then local people could see where the money generated from logging was going. He explained that 'at the moment buyers set the price, and local loggers only get a fraction of the market price because everything is illegal. But if the district government had more power, they could regulate the whole system. If the community made more profit, then the districtgenerated revenue (PAD) would increase. If more power was at the district level, the district government could also impose sanctions on transgressors'. 'There will still be timber theft and corruption', he said. However, cukong operating at the district level will be subject to greater social control: 'for instance, if we sit here as a group, and you take more than your fair share, I can bring pressure to bear on you'. ${ }^{67}$

In respect to moving towards more sustainable management of forest resources, the senior official in the district planning board maintained that solving the local community property rights issue constituted a key problem. In the past, 'a logging concession might have an annual work plan (rencana karya tahunan or RKT) from the Ministry of Forestry to cut twenty cubic metres per hectare, but they cut five times that amount.' This occurred before the eyes of local people who watched outside concessionaires obtaining the large rents generated from local forests. Consequently, after 30 years under this system, villagers 'have no sense of ownership - they see that it belongs to the logging concessions or the State - and they just cut it down'. However, he argued, it would be different if local people owned the forests. 'Village people still have high social values: people sit down together and reach an agreement about helping each other - to open ladang together. This kind of culture could be adapted for forest management. ${ }^{68}$ 

ON FOREST DEPENDENT COMMUNITIES IN BARSEL

As far as decentralisation enables local communities to have a greater say in how resources are managed, delegating decisionmaking powers to district government could enable forest dependent people to gain greater control over and enjoy more of the benefits from local forest resources. However, if regional autonomy occurs without the emergence of democratic controls at the district level, it is also possible that regional autonomy will enable local elites to extend their control over local forest resources. In other words, regional autonomy could improve the situation of local communities and/or lead to greater control of resources by regional elites.

The purpose of the following section is to consider the trends likely to shape outcomes in Barsel and assess the direction of current changes. In the course of this discussion, a number of other questions emerge. For instance, to what extent have community leaders been able to reassert community control over local forests? Is it likely that decentralisation will mean that government needs to consult more with communities during the decision-making process? With regional autonomy, will local communities gain a greater proportion of the rents generated from forest exploitation? Will the district be better off after these reforms are implemented? Moreover, do local people participate widely in logging activities or do they oppose the current epidemic of illegal logging? In short, with decentralisation, is it likely that a policy and legal framework will develop with greater participation from forest dependent communities and with due consideration to their property rights, needs and aspirations?

\subsection{RATTAN PRODUCERS IN BARSEL}

Long before timber became the economic star in Kalimantan's economic firmament, local people in Central Kalimantan depended on rattan exports. While rattan plays an important role in the economy of many villages in Barsel, reports concerning Barsel's forestry and agricultural sectors generally overlook the significance of rattan. Rattan is considered a non-timber forest product, and the Dayak people have long collected many varieties of rattan in the forests. However, for many years forest farmers have also cultivated two particular types of rattan, species known locally as rotan taman and rotan irit. In 1998 farmers cultivating these two varieties of rattan produced some 2,950,207 tons in addition to another $2,435,000$ tons of other rattan varieties (Badan Pusat Statistik Kabupaten Daerah Barito Selatan 1998).

Despite this productivity, rattan farmers have faced several difficulties. Rattan farmers enjoy only a small percentage of the price their product earns on the world market. This is largely a result of the long chain of traders between the rattan farmers and the consumers. After the rattan is 
harvested, farmers sell it on to a local collector, who in turn sells it on to a village trader. This trader peddles it on to a wholesaler who smokes the rattan. A 'regional rattan merchant' buys the processed rattan and then sells it to a 'national trader' who finally exports the rattan. In July 1998 , the price received by the farmer was around $\mathrm{Rp} 50,000$ to 60,000 per kuintal (100 $\mathrm{kg}$ ). The wholesale price of dried rattan was then Rp 180,000 to 200,000 per kuintal. At the same time, in Singapore rattan fetched over 1 million rupiah per kuintal (Madjen and Madjen 2000).

Problems arose for rattan harvesters in 1987, when the government passed a regulation that unprocessed rattan could no longer be freely exported. In effect, there was a 'one door' policy, and rattan could only be exported via processors in Java said to be associated with Mohamad 'Bob' Hasan, a close associate of President Suharto who served as Chair of the Apkindo plywood cartel and other forest industry associations (Barr 1999). According to a rattan wholesaler working in Buntok, this policy meant that the price of rattan fell from Rp 70,000 to Rp 30,000 per kuintal. ${ }^{69}$

Another issue emerged because Indonesian law classifies rattan as a subsidiary forest product (hasil hutan ikutan). This means that, to sell rattan legally, a rattan wholesaler had to obtain a timber transport permit (Surat Angkutan Kayu Bulat or SAKB) from the Ministry of Forestry. Until recently, the cost of the SAKB amounted to a $30 \%$ tax. This cost was passed on, reducing the price rattan farmers earned on their product.

The price of rattan improved when, following the fall of Suharto, the government abolished the "one door" policy and freed up the export of rattan. As rattan is an export product that remains in high demand, during Indonesia's 1997 economic crisis rattan prices (in rupiah terms) have increased, and rattan farmers have been able to weather the economic storm. At the height of the crisis, rattan prices increased to Rp 100,000 per kuintal. As a result, according to a rattan wholesaler, 'sixty percent of people in Barsel hardly felt the economic crisis. Villagers living on the Barito River cultivate rattan. Only those living in the highlands - who do not cultivate rattan - were badly affected'.

In December 1999 the Ministry of Forestry replaced the SAKB permit with a new permit known as a SHHBK (Surat Hasil Hutan Bukan $K a y u)$. The local forestry office no longer collects a tax on rattan, but rather by law is entrusted to grant the SHHBK on cultivated rattans free of charge. However, according to the rattan wholesaler, the SHHBK is now very difficult to obtain. While local forestry officials still diligently process permits on timber (which are still taxed), they will not process the SHHBK without large extra-legal fees. 'Before if I went to the Forestry Ministry with 3.6 tons of rattan, they would register it as 2.6 tons, and keep the tax payment on the extra tons... But now, because the permits carry no charge, they don't want to process it'. Consequently, to process the rattan legally, the wholesaler has to take the rattan down to South Kalimantan. There, he is forced to pay a fee to local wholesalers who then declare that the rattan was produced in South Kalimantan.

In May 2000, the district government regulation (discussed earlier) established a new tax on the harvesting of forest products (retribusi pemgambilan hasil hutan ikutan) that encompasses rattan. However, unless there is a change in the way SHHBK transport permits are issued, Barsel will fail to collect the retribusi of $1 \%$ per ton levied on the rattan. Although local rattan traders have attempted to take up the issue with the Bupati, he had been unable to resolve the problem when the research for this study was conducted. 'It will be very difficult for Barsel to progress', he concluded, "if officials behave like this". ${ }^{70}$ It is possible that, when CDK branch office of the Provincial Forestry Service becomes a Dinas under the authority of the Bupati, this problem might perhaps be more readily resolved. While reformasi appears to have improved the position of Barsel's rattan farmers, Popo and A'ung Madjen argue that many rattan farmers 
remain amongst the people in Barsel living below the poverty line. In an article on rattan farmers, they argue that rattan farmers lack capital and their rattan gardens tend to have low productivity. Moreover, as farmers are subject to high inflation, higher rattan prices have failed to convert into higher standards of living. Furthermore, the long succession of traders that separate the farmer from the consumer means that rattan farmers are subject to speculation further up the chain. This increases the likelihood of lower prices for their product, and rattan is subject to large fluctuations (Madjen and Madjen 2000). This was demonstrated most recently when rattan became the subject of a trade dispute between China and Indonesia. In June 2000 the Chinese government increased their import tax on rattan by $900 \%$. As China receives $80 \%$ of Indonesia's rattan exports, the price of rattan has begun to fall. ${ }^{71}$

Such is the fate of communities cultivating rattan gardens alongside the Barito River. However, the more heavily forested areas lie in the highlands. Accordingly, the study will now consider the fate of two communities living in the highland district of Gunung Bintang Awai, northeast Barsel.

\subsection{MUARA MARLUNGAI: THE SITUATION OF THE BAWO}

Muara Marlungai lies in the very northeast corner of Barsel near the border of Barito Utara and South Kalimantan. This is the homeland of the Bawo, an ethnic group practicing shifting agriculture and previously classified as an 'alienated group' (masyarakat terasing) by the Ministry of Social Affairs. Two HPH timber concession areas overlap the Muara Marlungai area, and to reach Muara Marlungai, visitors need to take PT Sindo Lumber's logging road. After turning off the logging road, the visitor first meets the transmigration settlement of Muara Marlungai (known as Muara Marlungai
Tran). Of the 300 transmigrant families settled here on the Bawo lands three years ago, now 100 families remain. These include thirty Bawo families who joined this program as 'local transmigrants' - enticed by the offer of new homes and a year's supply of basic commodities. From Muara Marlungai Tran, the visitor reaches the hamlet of Muara Marlungai after a two hour walk. ${ }^{72}$ In the 1970 s the Bawo were subject to various government development initiatives, including the program of the Social Affairs' office for 'the Developing Guidance of Alienated Groups' (Pembina Masyarakat Suku Terasing). However, the Bawo have been left impoverished and isolated, with most of their land logged over by the timber concessions.

These days, to supplement shifting agriculture and the meagre income from their rubber gardens, the Bawo cut timber. Although ironwood is now scarce close to Barsel's roads and rivers, the highly valued timber can be found around Muara Marlungai. ${ }^{73}$ Villagers sell ironwood to outsiders who provide capital and chainsaws. Village loggers can cut around one quarter of a cubic metre of timber into planks each day. Using bullocks, the loggers are able to drag out around one cubic metre per trip. They drag the timber to the road, and a single journey takes a whole day. From here trucks transport the wood down to the sawmills at Patas. While local people expend so much effort logging and transporting the timber, they obtain only a fraction of the ironwood's market value. Villagers sell the ironwood on to the middlemen for Rp 500,000 per $\mathrm{m}^{3}$, who then sell it on for $\mathrm{Rp} 2$ million per $\mathrm{m}^{3}$. As a result villagers remain poor. In Muara Marlungai we saw someone repairing a chainsaw, but unlike in other villages experiencing a logging boom, there was a noticeable lack of motorbikes, televisions, satellite disks or other signs of economic progress. Village informants said that, at best, villagers logging local forests might be able to buy a tin roof for their house.

The village head in Muara Marlungai said there is little to show from PT Sindo Lumber's village 
development (Bina Desa) activities. 'Although', he asked, 'how many billion rupiah have been taken from the area? If it was done justly, Muara Marlungai would be prosperous, because this is the heart of Barsel.' 'During the authoritarian years of the New Order,' he said, 'Sindo Lumber would not listen to the villagers. But now circumstances have changed: Sindo Lumber takes village requests more seriously.' Earlier this year he approached Sindo Lumber himself to request assistance. On May 21 the company called the village head down to Banjarmasin to discuss the issue. The village head wants to move Muara Marlungai to higher ground so that the village is not submerged by flood waters each year. Sindo Lumber has agreed to help prepare 400 ha for community agriculture, to build a bridge over the river, assist with housing, drinking water, the school and a ceremonial adat house. In many cases, the community development activities of logging concessions fail to meet the overly hopeful expectations of local communities. ${ }^{74}$ However, "the promise is now in writing,' he says, 'and it has been forwarded to the DPRD and the Bupati.' 'If they don't fulfil their promises,' he says, 'they can be called to the DPRD. ${ }^{75}$

Despite these indications that the Bawo would gain some bargaining power under the new arrangements, by the standards of Barsel, the economic and social circumstances of the Bawo remained extreme. Located just down the logging road from Muara Marlungai lies Sungai Paken, a hamlet of Patas, a village that is more representative. Sungai Paken and the administrative centre of Patas itself lie along the provincial road connecting Banjarmasin to Barito Utara and accordingly does not suffer the isolation and neglect found at Muara Marlungai. However, like Muara Marlungai, Patas village lands also overlap two logging concessions.

\subsection{PATAS VILLAGE}

According to village informants, during the 1960s, although there were four permanent villages east of the Barito River, at that time Sungai Paken and Patas had not been established as permanent settlements. At this time Ma' anyan Dayak would paddle by canoe eastwards upriver from the village of Danau Banbore. Local shifting cultivators would open ladang in the area, and after the harvest they would return to their mother villages.

Sindo Lumber began operations here in 1968, and from this time Sindo Lumber and other concessionaries opened roads to extract the timber. As timber operations extracted large trees, forest areas lost some of their capacity to retain water, changing the hydrology of what had been a heavily forested area. Consequently, except during particularly wet periods, the upstream course of the rivers were less navigable. Now villagers tend to use the roads, and the rivers now only used occasionally to transport timber, rubber or locally constructed boats down to the Barito River.

Sindo Lumber is now logging up in the far corner of Barsel behind Ngurit, a hamlet of Patas north of Muara Melangai. From here timber trucks carry the timber down to their log pond at Pendang, some $63 \mathrm{~km}$ away. The logs are then towed down to Banjarmasin, where Sindo Lumber has a mill. According to a worker interviewed in Sungai Paken, only 3 residents of this hamlet work for the company. One worker reported that production has been falling slightly over the last year. Although he did not wish to discuss Sindo Lumber's schedule in specific terms, he estimated that at most Sindo Lumber would be able to extract timber from this concession for another 10 years. However, this estimate may be overlyoptimistic: to anticipate the day when the company would close its operations, he has already begun preparing his own rubber gardens. ${ }^{76}$ 
According to villagers, Sindo Lumber never had to take account of adat rights of the Ma'anyan Dayak in their operations under Suharto's New Order regime. The Ma' anyan had not established a permanent village here before Sindo Lumber started its operations, and shifting cultivators using the area had failed to develop legally recognised territorial boundaries that could be defended against the granting of a concession over surrounding forests. This meant that, based on the legal rights over the concession area granted by the central government, during the New Order period Sindo Lumber excluded villagers from the area: villagers could not open ladang inside the concession. Yet, after the downfall of Suharto, this has changed. The concessionaire could no longer rely on the support of officials in excluding local people from previously logged over areas.

Sindo Lumber allows villagers to use their logging road as far as the hamlet of Ngurit. Beyond that lies the company's active logging block, an area guarded by the company's own security personnel. Villagers are forbidden from travelling beyond there without the company's permission. While villagers now opened plots in the areas below, many continue to resent the logging operation. One villager explained that the graders employed in timber operations turn over the top soil, which is then buried or washed away by the rains. This makes it difficult for the forest to regenerate, he said or for farmers to open ladang in many logged over areas.

According to the head of Patas village, the logging concessions operating in the vicinity have recently become more responsive to local needs. Another concession, Tanjung Lingga, has built a bridge for the community and contributed funds to a local Islamic boarding school (pesantren). Sindo Lumber is also now involved in helping the village, but only if the village head requests the company's assistance. Even then he needs to remind them two or three times before they will fulfil a promise. ${ }^{77}$ Yet, Sindo Lumber has recently had disputes with local villagers. Although he would not describe the problem in any detail, an employee of Sindo Lumber said that in early 2000 there was a demonstration against the company. ${ }^{78}$ According to the village head, Sindo Lumber started planting an area of land for a timber plantation. Although Sindo Lumber asserted that the lands were unused, villagers claimed that the fallow areas were in fact community lands. As the problem threatened to escalate, the village head made representations on behalf of the community, and Sindo Lumber withdrew. ${ }^{79}$

The head of Patas Village reported that 11 bansaw (simple one blade mills) have opened in the village - along the highway to Barito Utara - in the last year. He noted that none of these bandsaws has an official permit. The village head says that the entrepreneurs (cukong) who open the sawmills are of Banjar ethnicity, and most of the work force also comes from Negara, South Kalimantan. ${ }^{80}$ The Banjarese newcomers constitute about $5 \%$ of the village's population. The in-migrants mostly work in the sawmills; when the timber is finished the village head expects they will leave.

The timber comes from surrounding forests, including inside Sindo Lumber's concession area. An employee of Sindo Lumber reported that the company was unable to prevent loggers from surrounding villagers cutting in previously worked over areas inside the concession of PT Sindo Lumber. 'How can we stop it?' he asked. 'The people are doing it and the government doesn't take any action.' The loggers cut timber, building up a stock first. They then make an appointment with buyers with trucks who come and carry the timber out. Alternatively, when the river is high during the wet season, the loggers float rafts down the river. ${ }^{81}$

In Patas, a truck driver from Buntok described how he has bought two chainsaws for Rp 2.5 million. He used to rent a chainsaw to loggers working near Bundar, close to the Barito River. After timber became scarce there, he moved the operation east, lending the chainsaw to villagers in Tabakkanilan area closer to Patas. Although 
the villagers are able to $\log 5-7 \mathrm{~m}^{3}$ of timber per day, the problem is getting the wood out. 'We have a lot that has rotted,' he said. 'We share the profit', he explained. 'Every two weeks I come and collect one million rupiah [from those operating the chainsaws]'. 'If you had three chainsaws', his friend added, 'you would not have to work at all. Every 2 weeks you could collect Rp 3 million. ${ }^{, 82}$

Later in Buntok, after returning from a visit to the chainsaw operator, the driver explained the situation of the chainsaw operator. The logger had a rubber garden, but no rattan. He cuts timber while his wife works in the rubber garden. After paying his friends, every two weeks the logger earns approximately half a million rupiah. When asked to describe their situation, the driver said that they have little to show for their work. 'They cannot buy a motorcycle, television or fix their house. They earn enough to eat... The difference with the Bawo,' he said, 'is that the Bawo have to use a bullock to drag the wood out. Here they are near a road, and the wood can be taken out by truck.' ${ }^{83}$

The head of Patas village is more sanguine about logging. The first time we encountered him, it was at the sawmill of one of Barsel's chief cukong. In his view, many of those active in the timber industry progress economically. Like the village head himself - who has bought a new tile roof for his house - they are able to refurbish their houses. 'Those who are smart', he says, 'are involved in the timber business.... ${ }^{84}$

The hamlet of Sungai Paken sits right where PT Sindo Lumber's logging road intersects the provincial highway. While sipping tea in the village's warung, visitors can watch huge logging trucks coming down the logging road en route to the company's log pond down on the Barito River. According to villagers interviewed in the warung, only some locals are involved in the illegal logging, working with chainsaws or helping transport the timber. 'These people have no other job,' one explained, 'so they work with timber'. However, he added, 'most of us just watch'. 'I don't like to think what our grandchildren will do', an older man says. 'No timber of any value is left. If the forest is thin, where will we get building materials. We won't be able to collect damar or rattan in the forest. People will only be able to work in their rubber gardens, if they have any'.

The unanimous view amongst those sitting in the warung was that outsiders were taking the lion's share of the benefits. While some villagers were involved in the unauthorised logging, most were just standing by and watching as the environmental conditions on which shifting agriculture depended continued to deteriorate. When asked about whether recent political changes have improved their situation, villagers were less than cheerful: 'Reformasi has meant a lot to entrepreneurs (pengusaha)', one said. 'They can fill their bellies, but it hasn't meant much to us' ${ }^{85}$ 


\section{CONCLUSIONS}

After the end of Suharto's New Order regime, previously existing national government controls over access to and use of the statedefined 'Forest Estate' (Kawasan Hutan), such as they were, have lapsed. With the withdrawal of government security support for timber concessions, the bargaining position of logging concessions has declined. Timber concessionholders now have to make concessions to local communities. In most areas - with the exception of active RKT cutting blocks -HPH-holders are unable to control access to and use of timber in their concession areas. This is associated with an upsurge in logging outside the official forestry regime.

While access to forest resources during the New Order period was largely controlled by the national government's HPH timber concession regulations, now access is more a matter of economics. An office worker in Buntok who had tried to open a small timber business without a formal permit explained that those intending to operate timber operations outside the law face considerable expenses. He had operated a small sawmill supplied by chainsaws operates harvesting logs from secondary forest and exporting wood out of the area. Yet, forestry officials kept approaching him when he wished to extract the timber. 'They would ask for $\mathrm{Rp}$ 25,000 or more every time they met me. Sometimes, they would come in groups of five to eight people', he recalled. 'It was too expensive - there were no profits.' So he stopped his operation.
Yet operators wishing to gain an official permit face enormous expenses. According to one sawmill operator interviewed in the course of this study, it costs Rp 700 million to obtain the permit (Rencana Pengurusan Bahan Baku Industri or RPBI) issued by the Ministry of Forestry's regional office (Kantor Wilayah or Kanwil) in Palangkaraya. This RPBI permit allows sawmill operators to formally obtain permits to transport timber out of the district. ${ }^{86}$

To find a way around these unattractive alternatives, small scale sawmill operators who cannot afford the RPBI enter into business relationships with operators (known as cukong) who have made this investment. If they sell their timber to such a cukong, he can then export the timber legally. Wealthier cukong tend to have legal business permits and close relations with senior functionaries and politicians: their business operations operate openly, and to some extent small-scale operators can operate their business under this umbrella.

Recent legislation initially opened other routes for gaining legal access to timber. District actors can form cooperatives and request $\mathrm{HPH}$, HPHKM or HPHH concession permits in the name of their cooperatives. However, after Ministry of Forestry and Estate Crops delayed the implementation of the laws providing for these permits in late 1999, line agencies in Barsel - namely the CDK branch office of the Provincial Forestry Service - have deferred executing the new initiatives. 
Yet, as in other districts, the avenues for gaining access to timber appear to be expanding as regional autonomy is introduced. During 2000, the district began experimenting with a new district regulation that validates timber harvested outside the official forestry regime. According to this new regulation, timber would be allowed to be exported on the understanding that those involved pay taxes due to the central government as well as a newly created district levy on forest products. As noted earlier, attention would be paid to whether the timber had been subject to taxes rather than whether it had been legally harvested. By taxing the network of exchange already operating in the district, the initiative in effect legalised illegal logging. Forestry officials at the district level now had the authority to issue timber transport permits (Surat Keterangan Sahnya Hasil Hutan or SKSHH). ${ }^{87}$ The local forestry office (CDK Barito Hilir) was still under the Governor's authority (through Dinas Kehutanan Tingkat I) before the inception of regional autonomy. This meant that the initiative had to be coordinated with the provincial authorities. At the time that this research took place, higher authorities had not created administrative obstacles to proceeding with the initiative: it appeared as though the higher level forestry offices were taking a permissive attitude towards this initiative, as long as the district also collected the DR and PSDH taxes.

However, villagers continue to have a poor position within the network of exchange and accommodation surrounding logging. Although some villagers are involved in illegal logging, they lack the capital to buy chainsaws, open sawmills or form cooperatives. They also lack the funds or contacts to obtain official permits or pay the unofficial gatekeepers extra-legal fees. Consequently, villagers who join illegal logging operations usually work as poorly paid labourers and obtain few benefits. When they do operate independently, they sell the timber at low prices to larger operators who obtain most of the profits. Meanwhile, impoverished local communities face the negative externalities of the timber industry.
Moreover, there tends to be an ethnic aspect to the "social gap" emerging around logging. Those with the capital to open and operate timber businesses tend to be Banjarese or other in-migrants. Meanwhile, most indigenous Dayak communities watch on: at best, poor villagers work as labourers in the forest. In effect, most of the profits from illegal logging go to outsiders. This creates an ethnic dimension to the division between those profiting and those left with the environmental consequences. As this cleavage also reflects a religious difference between the largely Islamic in-migrants and the Dayaks mostly of Christian or Kaharingan belief, some Dayak commentators felt that this would later lead to ethnic conflict.

Clearly, the implications of decentralisation for Barsel's forests are closely bound up with the policies of the district administration. Prior to regional autonomy, the district government only generated $2.1 \%$ of its budget through its own taxes and levies. In the run-up to regional autonomy there is enormous pressure to increase the district's PAD, and the district government planned to increase PAD by $438 \%$ in 2000 . Fiscal pressures of this sort are likely to affect district policies in at least two significant respects.

First, the district has embarked on creating a district government-owned enterprise or BUMD. In its first years the BUMD will rely heavily on forest exploitation. If it can obtain rights over significant forest areas from Inhutani III, the BUMD aims to generate its working capital as well as revenue for the district government by extracting timber from previously logged-over forests. While this logging will be done nominally to make way for plantations, as noted earlier there are serious obstacles to the creation of viable plantations.

Second, the need to generate revenue has affected the district's attitudes to illegal logging. With regional autonomy the district will have greater powers to create its own legislative regime, and the district is using this power to handle the problem of extra-legal logging by 
emphasising the revenue generating potential of the timber industry. The emerging regime attends to the taxation status of the timber rather than the question of whether the timber was extracted in accordance with regulations that aim to protect the long term sustainability of either the timber industry or the local environment.

It is sometimes argued that decentralisation may create greater community participation in government, leading to greater community control over local resources that in turn will entail more sustainable resource use. ${ }^{88}$ However, at present it is questionable whether decentralisation in Barsel will lead to greater community control. To be sure, the ability of elements of the state apparatus to operate on behalf of regional or national elites has weakened following the end of the Suharto period. As local communities enjoy greater bargaining power in discussions and disputes with logging concessionaries and other actors, they can protect their interests more effectively. Consequently, the community enjoys greater access to local forests, even if they lack the economic power to enjoy the benefits of this access. However, to date decentralisation has not been associated with reforms that confront the property rights issue underlying the lack of community control over local forest resources. In the context where communities experience economic scarcity, local entrepreneurs seek new opportunities and the district government needs to raise revenue, greater access is leading to a race to capture forest resources. There are few incentives or opportunities for instituting control - for communities to regulate or otherwise exert ownership over surrounding forests for their own long-term benefit.

While decentralisation in Barsel amounts to the transfer of some powers to district government, it is unclear whether this will necessarily empower local communities. There is clearly a disjunction between the elite making policy at the district level and the district entrepreneurs making the most of opportunities created by these policies, on the one hand, and the fate of the isolated indigenous communities of Barsel, on the other. Local communities are not yet involved in the policy making process and enjoy little influence over what is occurring. Meanwhile, they continue to see their resource base diminished.

Rather than seeing decentralisation as the causal factor behind the current pattern of resource extraction, the present situation is best viewed as a continuation of previous exploitation. In most areas, logging concessions have taken the larger trees over previous decades leaving extensive secondary forests in various stages of rejuvenation. In some of these areas significant strands of timber remain. Thus for illegal loggers have generally lacked heavy equipment and have only been able to gain access to the more accessible areas - relatively close to logging roads and rivers. Logging in these areas now continues unabated. While this researcher was unable to find accurate data on the volume of timber currently being extracted, several informants noted that the size of the logs has continued to fall while types of timber that previously lacked value are now being taken. A forestry officer stationed on the Barito River also observed that the overall volume of timber passing down the Barito River has continued to decline significantly over the last ten years. Yet, other informants explained that when water level is high, large volumes of timber continue to flood the river. Large-scale timber operations have taken the forest giants and now small-scale logging operations are taking smaller trees and varieties that were previously left behind. The ecological implications of current trends are unambiguous: the process of unsustainable logging associated with high levels of forest degradation is continuing.

Yet, despite some of these less savoury implications, when compared to the highly centralized system of forestry sector governance maintained under the New Order regime, there are some positive aspects to the decentralized system that is emerging. A number of district figures argued that under the system that is now emerging, it is likely that more of the rents generated from logging are likely to stay in the 
local economy. They offered a number of reasons to support this assertion. First, while logging concessions generally employed outsiders, now some of the local people are engaged in the informal timber industry and do receive some benefits. Second, the district government is now making significant efforts to collect district taxes on these activities. This revenue will also circulate in the district economy, to some degree supporting local priorities. Third, local entrepreneurs are tied into local clientelist patterns: as patrons, they are obliged to contribute to local activities. For instance, in the course of this study, local informants spoke of district entrepreneurs contributing capital towards the nascent BUMD district enterprise, renovating a local mosque and building a residence hall (asrama) for students from the district taking up studies in Palangkaraya. Compared to when Jakarta based politico-business families exclusively controlled logging concessionaires, to some degree this system will contribute to district development - at least for as long as the timber lasts.

However, in mid-2000 when this research was undertaken, there was a lack of information about the amount of funding the central government would transfer to the regional government after implementation of the decentralisation laws in January 2001. Consequently, despite the district revenue generated from the timber sector, it was unclear whether the district would be better off in absolute terms. It was also possible that, if transfer payments from the central government fell substantially under regional autonomy, even if the district government could capture a larger amount of rent from timber exploitation, the financial position of the district might decline. Moreover, in the long term, increased local employment, the minor contribution of district entrepreneurs, and the increase in district revenues may amount to a small, temporary compensation for the rapid, unsustainable exploitation of the district's timber reserves. 


\section{ENDNOTES}

${ }^{1}$ While there are plans now under discussion to divide Central Kalimantan into new districts, at present Barsel consists of 12 subdistricts.

${ }^{2}$ In the subdistricts of Jenamas and Dusun Hilir on the western bank of the Barito River.

${ }^{3}$ Interview, Camat Dusun Hilir, 25.7.00

${ }^{4}$ This is in the region surrounding the towns of Ampah (subdistrict Dusun Tengah) and Tabakkanilan (subdistrict Gunung Bintang Awai).

${ }^{5}$ By 1999 more than 18,000 transmigrants had settled in more than 23 transmigration settlements across the district (Pemerintah Kabupaten Barito Selatan 1999a) .

${ }^{6}$ For instance, oil palm producers can directly export their product to Java from the port of Sampit. With decentralisation each province and district can impose taxes on goods and services. If Central Kalimantan's Barito districts impose taxes on goods or services, and South Kalimantan also imposes it's own taxes on products passing through, products will be taxed twice. There is a need for strong coordination across the regions.

${ }^{7}$ Interview, Egerson Komeng, Bapedalda, 22.7.00.

${ }^{8}$ In Gunung Bintang, Patas Subdistrict.

9 This is in the Kecamatan Awang area. Banjarmasin Post, 2000a.

${ }^{10}$ This area was subsequently divided up, and a section has been allocated to PT Hasnur Jaya Utama

${ }^{11}$ PT Hasnur Jaya Utama obtained part of the 125,000 ha area formerly managed by Inhutani
III (part of the former concession area of PT Rimbayu Barito).

${ }^{12}$ Interview with village head, Patas, 23.7.00. This is the former concession area of PT Djayanti Djaya I.

${ }^{13}$ PT. Sindo Lumber in partnership with PT. Perwata Rimba.

${ }^{14}$ As noted later, in 2000 the forestry office in Buntok (CDK Barito Hilir) remained a branch office (cabang) under the authority of the Dinas Kehutanan at the provincial level. These branch offices had responsibilities for particular watershed areas rather than districts areas.

${ }^{15}$ See McCarthy (2000a).

16 This is a small sum of money. Informants noted that dividends were not divided equally between the members of the cooperative. (Interview, Dinas Koperasi 19.7.00). If they had been, this would only amount to US\$14/person.

${ }^{17}$ Interview, Dinas Koperasi, 19.7.00. The requirement to involve small and medium size businesses and cooperatives in logging concession operations might include subcontracting such parties to transport oil for and buying timber.

${ }^{18}$ Interview, Dinas Koperasi, 19.7.00.

${ }^{19}$ In the town of Rantau Kujang.

${ }^{20}$ Interview, 24.7.00. In Kalteng people distinguish a bansaw (i.e. a bandsaw) - a simple sawmill blade that is able to cut logs into simple planks - from a sawmill - a more sophisticated lumber mill that has many types of blades and is able to produce a variety of types of lumber. While a sawmill tends to be bigger and more 
permanent type of lumber mill, bansaw are smaller and more mobile. Accordingly, bansaw tend to mover around, and during 2000 many could be found at strategic positions on road and rivers.

${ }^{21}$ Interview, Camat Dusun Hilir, 25.7.00

${ }^{22}$ Interview, confidential source, Jenamas, 24.7.00. Accurate information regarding the legal status of sawmills is notoriously difficult to obtain. However, it is important to differentiate the different varieties of sawmill permits. Those operators with IPK permits or RPBI - the nine mentioned earlier - can formally obtain permits to transport timber out of the district. Other sawmills only have licences for post-production industries (moulding).

${ }^{23}$ As this table lists only the most significant items in the district budget, it does not list all the items in this budget. Therefore, the total district income is not the total of all the components listed below, and neither do the expenses components do not add up to 83 billion. These figures are rounded to the nearest hundred thousand rupiah.

${ }^{24}$ Total receipts (penerimaan) is the sum of district income (penerimaan daerah) and 'cash business and transactions' (urusan kas dan perhitungan).

${ }^{25}$ Please note, this table contains only the most significant items, and therefore the figures in the second column do not add up.

${ }^{26} \mathrm{PBB}$ is a land and building tax levied that is levied on logging concessions and mining operations. It is important to note that these two categories are not sub-categories of regionallygenerated income.

${ }^{27}$ According to the fiscal balancing law (UU No 25/1999) $80 \%$ of IHPH and PSDH revenues generated from the forestry sector will be allocated to the regions with $64 \%$ being allocated to the district of origin. In addition, $40 \%$ of DR (which are included under the dana alokasi khusus category) will also be allocated to the districts to carry out reforestation activities. Informants noted that previous legislation enacted during the New Order regarding the division of revenues had already allocated similarly high proportion to the regions. However, the legislation had never been fully implemented or, due to the lack of transparency in the process, the central government had held the lion's share of revenues generated from this sector. Now, given the fiscal problems facing the central government and the lack of trust district officials place in the transparency of record keeping, there was some scepticism among informants that the new legislation would markedly alter the revenues that the districts would received from timber concessions.

${ }^{28}$ Brian Belcher, personal communication.

${ }^{29}$ Interview, BAPPEDA, 27.7.00.

${ }^{30}$ The 'general allocation' will be calculated with a regional weighting (bobot daerah) that will be "established according to the extent of the district and its population density. This means that the Central Kalimantan area that has a low population will certainly have a poor ability to attract the 'general allocation'. Popo Madjen 'Otonomi Daerah, Antara Benci dan Rindu,' paper presented at meeting entitled, 'Obrolan Santai dan Curah Pendapat tentang Pengelolaan Sumberdaya Alam Dalam Kerangka Otonomi Daerah di Kalimantan Tengah', WALHI Kalimantan Tengah, Palangka Raya, 15 April 2000.

${ }^{31}$ Discussion with Popo Madjen, 27.7.00. In addition to this, the 1997 law (UU No 18/1997) reduced the ability of districts to raise taxes from the forestry sector.

${ }^{32}$ Interview, Dispenda, 20.7.00.

${ }^{33}$ Interview with hospital worker, Buntok, 21.7.00.

${ }^{34}$ These new perda are enacted by the district government to raise revenue for the district. According to the decentralisation laws (UU 22 $\& 25$ ), the districts have the right to raise revenue outside areas do this and are not obliged to share any revenue they gain with the provincial level. However they are obliged to tell the province (as representative of the centre) about any new perda within 15 days. And province/centre can cancel it. 
${ }^{35}$ Interview, 21.7.00.

${ }^{36}$ The concept of Forest Product Harvest Concession (Hak Pemungutan Hasil Hutan or HPHH) was established by a 1999 law (Peraturan Pemerintah No 6/1999). This law gave the Bupati power to give permits for HPHH for areas of up to 100 ha. HPHH is a right to harvest timber and non-timber forest products from 'production forest' in areas subject to the HPHH. The new basic forestry law (UU No 41/1994) changed the name of HPHH to Ijin Pemungutan Hasil Hutan (IPHH). However, implementation of this law was suspended by a letter from the Ministry of Forestry and Estate Crops (Dephutbun) in November 1999. Dephutbun suspended the law following the installment of a new Forestry Minister apparently because the HPHH insufficiently paid attention to the problem of reafforestation. There were also fears that the implementation of the HPHH initiative was tainted with corruption and collusion (Interview, Kanwil Kehutanan Palangkaraya, 8.6.00). This policy change occurred before the Barsel government was able to move ahead.

${ }^{37}$ This criticism is frequently heard in Central Kalimantan. (Telescope 2000).

${ }^{38}$ At Gagutur (in the former concession area of PT. Guntur Gempita).

${ }^{39}$ This lies in the Pararapak area, in the former concession of PT Rimbayu Barito.

${ }^{40}$ In early 2000, a decision was made to discontinue transmigration in Central Kalimantan. The researcher had no opportunity to clarify how this had affected the IPK discussed here. 'Central Kalimantan closed to migrants', Jakarta Post, March 15, 2000.

${ }^{41}$ BUMD has also requested for raw materials from two HPHs operating in the area who are by law obliged to provide $5 \%$ as raw material for local timber production.

${ }^{42}$ Popo Madjen, 19.7.00.

${ }^{43}$ Interview with Dinas Perindustrian, Barsel, 19.7.00.

${ }^{44}$ For a discussion of this phenomena, see
McCarthy (2000b), Barr (2001) and ITFMP (1999).

${ }^{45}$ Bupati Barito Selatan, Peraturan Daerah Kabupaten Barito Selatan nomor : 2 Tahun 2000 Tentang Retribusi Hasil Hutan, Hasil Hutan Bukan Kayu dan Hasil Perkebunan. Although the charge is new for Barsel, similar to taxes levied by other regional governments before the implementation of UU No 18/1997 (McCarthy 2000b).

${ }^{46}$ As noted in an earlier footnote, under UU 25, $64 \%$ of PSDA and IHH revenues come back to the district level, and in that sense they are already taxed by the district. Moreover, PP No 25 suggests that the district government has limited powers in this respect.

${ }^{47}$ By comparison, in Kapuas the Bupati continued to implement the HPHH initiative via the Dinas PKT which, even before the implementation of regional autonomy, falls under the Bupati's authority rather than the Governor's. However, in Barsel the Dinas PKT was formed only three years ago. The Dinas PKT does not have its own office, and operates out of the Bupati's office. In comparison, in Kapuas the Dinas PKT is a large and separately functioning office. This enabled the Bupati in Kapuas to continue with HPHHs without the active involvement of the CDK (see Kapuas case study).

${ }^{48}$ Muspida, musyawarah pimpinan daerah, a council of key district level government officials involving the Bupati and the heads of the district police and military.

${ }^{49} \mathrm{PSDH}$ amounts to $\mathrm{Rp} 64,000 / \mathrm{m}^{3}$ for Meranti $\mathrm{Rp} 36,000 / \mathrm{m}^{3}$ for mixed timber (rimba campuran) while the DR amounts to US\$ 16/ $\mathrm{m}^{3}$ for meranti and US $\$ 13 / \mathrm{m}^{3}$ for mixed timber (rimba campuran).

${ }^{50}$ Muspika, musyawarah pimpinan kecamatan.

${ }^{51}$ Confidential source, Buntok, 25.7.00.

${ }^{52}$ Confidential source, Buntok, 25.7.00.

${ }^{53}$ Banjarmasin Post, $2000 \mathrm{~d}$. 
${ }^{54}$ As noted earlier, the bupati formed the team collecting the retribusi after a Muspida meeting. The district police chief is a member of the Muspida and obliged to conform to its consensual decisions. However, informants noted that the police were unhappy with the new system, they obliged to go along with the decision.

${ }^{55}$ Confidential source, Buntok, 25.7.00.

${ }^{56}$ Interview with Triyono Bioti, Wakil Kepala, CDK Barito Hilir, 21.7.00.

${ }^{57}$ Banjarmasin Post 2000c.

${ }^{58}$ Discussion with Popo Madjen, 21.7.00.

${ }^{59}$ Brian Belcher, personal communication.

${ }^{60}$ Interview, BAPPEDA, 26.7.00.

${ }^{61}$ Interview, BAPPEDA, 27.7.00.

${ }^{62}$ Interview, BAPPEDA, 26.7.00.

${ }^{63}$ Interview, BAPPEDA, 26.7.00.

${ }^{64}$ Interview, Bapedalda, Palangkaraya, 17.7.00.

${ }^{65}$ Interview, Aji Rario, 21.7.00.

${ }^{66}$ Interview, Kepala Dinas Kehutanan, Palangkaraya, 16.7.00.

${ }^{67}$ Interview, BAPPEDA, 27.7.00.

${ }^{68}$ Interview, BAPPEDA, 27.7.00.

${ }^{69}$ Interview, 25.7.00.

${ }^{70}$ Interview, 25.7.00.

${ }^{71}$ Interview, 25.7.00.

${ }^{72}$ Muara Marlungai is the original village. However the government encouraged the Bawo to abandon their original village and move down to the more accessible site of Bintangara. After the implementation of the village government law, Muara Marlungai was given hamlet (dusun) status and the administrative centre of the village was located at Bintangara. Then three years ago the government opened the transmigration settlement of Muara Marlungai Tran. The hamlet head of Muara Marlungai now resides at Muara Marlungai Tran.

${ }^{73}$ For a discussion of traditional rights over ironwood and the impact of logging concession operations on community logging, see Peluso (1992).

${ }^{74}$ For other examples, see Kapuas case study.

${ }^{75}$ Interview, Kepala Dusun Muara Marlungai, 23.7.00.

${ }^{76}$ Interview, Sindo Lumber timber worker, 23.7.00.

${ }^{77}$ Interview village head, Patas, 23.7.00.

${ }^{78}$ Interview, Sindo Lumber timber worker, 23.7.00.

${ }^{79}$ Interview village head, Patas, 23.7.00.

${ }^{80}$ Interview village head, Patas, 23.7.00.

${ }^{81}$ Interview, Sungai Paken, 23.7.00.

${ }^{82}$ Interview, Sungai Paken, 23.7.00.

${ }^{83}$ Interview, 27.7.00.

${ }^{84}$ Interview village head, Patas, 23.7.00.

${ }^{85}$ Interview, Sungai Paken, 23.7.00.

${ }^{86}$ Interview, 27.7.00.

${ }^{87}$ SKSSHH replaced the SAKO/SAKB permits from June 12, 2000.

${ }^{88}$ For a discussion of this issue, see Kaimowitz et al. 1998. 


\section{REFERENCES}

Ascher, W. 1995. Communities and sustainable Forestry in developing countries. San Francisco: ICS Press.

Badan Pusat Statistik Kabupaten Daerah Barito Selatan. 1998. Barito Selatan dalam angka tahun 1998. Badan Pusat Statistik Kabupaten Daerah Tingkat II Barito Selatan.

Banjarmasin Post. 2000a. Sumur Minyak Jadi Andalan. Http://www. indomedia.com/bpost August 26.

Banjarmasin Post. 2000b. Perda Kayu Legalkan Kayu Ilegal. Http://www. indomedia.com/ bpost. August 18.

Banjarmasin Post. 2000c. Barut-Barsel Rebutan Kayu Sitaan. Http://www. indomedia.com/ bpost. August 12.

Banjarmasin Post. 2000d. Tim kayu berhasil raup $R p 5 M$. Http://www.indomedia.com/ bpost. May 20.

Banjarmasin Post. 2000e. Jalan Palangka Raya-Buntok dievaluasi. Http://www. indomedia.com/bpost. March 30.

BAPPEDA 1999. Revisisi recana tata ruang wilayah (RTRW) Kabupaten Barito Selatan tahun anggaran 1998/1999. Pemerihtah Kabupaten Daerah Tingkat II Barito Selatan.

Barber, C.V., Johnson, N. and Hafild, E. 1994. Breaking the logjam: Obstacles to forest policy reform in Indonesia and the United States. World Resources Institute: Washington, DC.

Barr, C. 1999. Discipline and accumulate: State practice and elite consolidation in Indone- sia's timber sector, 1967-1998. M.Sc. Thesis. Cornell University. Ithaca, NY.

Barr, C. 2001. Banking on sustainability: Structural adjustment and forestry reform in Post-Suharto Indonesia. Washington, DC: Center for International Forestry Research and WWF Macroeconomics Program Office.

Barr, C. and Resosudarmo, I.A.P. 2001. Decentralisation of forest Administration in Indonesia: Implications for forest sustainability, community livelihoods and economic development. Draft. Center for International Forestry Research .Bogor, Indonesia.

Brandon, K.E.and Wells, M. 1992. Planning for people and parks: Design dilemmas. World Development 20 (4):557-70.

Carney, D. 1995. Management and Supply in Agriculture and Natural Resources: Is decentralisation the answer? Overseas Development Institute Natural Resources Perspectives No 4. London: Overseas Development Institute.

Casson, A. 2001. Decentralisation of policymaking and administration of policies affecting forests and estate crops in Kotawaringin Timur District. Central Kalimantan. Center for International Forestry Research, Bogor, Indonesia.

Conyers, D. 1981. Decentralisation for regional development: A comparative study of Tanzania, Zambia, and Papua New Guinea. Public Administration and Development 1 (2):107-20. 
Dinas Kehutanan Cabang Dinas Kehutanan Barito Hilir 2000. Laporan tahunan cabang dinas Kehutanan Barito Hilir 1999/2000. Pemerintah Daerah Tingkat I Kalimantan Tengah Dinas Kehutanan Cabang Dinas Kehutanan Barito Hilir.

Indonesia-UK Tropical Forest Management Programme (ITFMP). 1999. Illegal logging in Indonesia. Report No PFM/EC/99/03.

Jakarta Post. 2000. Central Kalimantan closed to migrants. March 15.

Kaimowitz, D., Vallejos, C., Pacheco, P. and López, R. 1998. Municipal Governments and Forest Management in Lowland Bolivia. Journal of Environment and Development 7 (1): 45-59.

Kalteng Pos. 2000. Rp 1,7 M 'tercecer' di DAS Barito. May 12.

Lay, C. 1999. The management of natural resources for the strengthening of the local base: The social and political perspective. Introductory Notes. Paper presented to the Seminar-Workshop Towards the Management of Natural Resource for Strengthening of the Local Base, YLBHIPublicity and International Relations Division (PIRD), Jakarta, 1999.

Madjen, P. and Madjen, A.U. 2000. Mengentas petani rotan dari kemiskinan. Media Kalteng, May 5.

McCarthy, J.F. 2000a. Implications of regional autonomy for forest management. Paper presented to the Paper presented to the 2nd Insela Conference on Decentralisation and Environmental Management in Indonesia, Jakarta.

McCarthy, J.F. 2000b. 'Wild logging': the rise and fall of logging networks and biodiversity conservation projects on Sumatra's rainforest frontier. Occasional Paper 31, Center for International Forestry Research.

Ostrom, E. 1990. Governing the commons: The evolution of institutions for collective action. Cambridge: Cambridge University Press.
Peluso, N. 1992. Rich forests, poor people: resource control and resistance in Java. University of California Press. Berkeley.

Pemerintah Kabupaten Barito Selatan 1999a. Barito Selatan Selayang Pandang.

Pemerintah Kabupaten Barito Selatan 1999b. Data pokok pembangunan daerah Kabupaten Barito Selatan 1998/1999.

Rieley, D.J. 1999. Death of the Peat Swamp Project'. Http:/www.geog.nottingham.ac.uk/ $\sim$ rieley/Dartrop/dartrop.htm.

Rivera, R. 1996. Decentralización y gestión local en América Latina. FLACSO, San Jose.

Rondinelli, D., Nellis, J.R. and Cheema, G.S. 1983. Decentralisation in developing countries: A review of recent experience. Staff Working Papers No 581. Washington D.C.: World Bank.

Scotland, N., Frazer, A., and Jewell, N.. 1999. Roundwood Supply and Demand in the Forest Sector in Indonesia. Indonesia-UK Tropical Forest Management Programme, Report No PFM/EC/99/08 (November 23 ${ }^{\text {rd }}$ draft). Jakarta, Indonesia.

Sunderlin, W.D., Resosudarmo, I.A.P., Rianto, E., and Angelsen, A. 2000. The effect of Indonesia's Economic Crisis on Small Farmers and Natural Forest Cover in the Outer Islands. Occasional Paper No 28(E). Center for International Forestry Research, Bogor, Indonesia.

Telescope 2000. PT Inhutani III serakah: Kepentingan daerah diabaikan. No 3, July.

Toha, M. 2000. Estimated deforestation rate for Indonesia. Unpublished presentation prepared for the CGI Seminar on Indonesian Forestry. Jakarta. January 26.

Utting, P. 1993. Trees, people, and power: Social dimensions of deforestation and forest Protection in Central America. Earthscan, London.

World Bank. 2001. Indonesia: Environment and natural resource management in a time of transition. World Bank, Washington, DC. 
